\title{
TECAMACHALCO Y EL PINTOR INDFGENA JUAN GERSON
}

\author{
Por Xavier Moyssén.
}

ENTRE las fundaciones conventuales importantes que hicieron los franciscanos en la primera mitad del siglo xvi, se encuentra la que corresponde al antiguo pueblo prehispánico de Tecamachalco, Puebla. El 13 de agosto de 1541 fray Diego de Estremera, guardián del convento de Tepeaca, realizó la primera incursión a Tecamachalco, lugar habitado por indígenas popolocas; y antes de finalizar el año, fray Francisco de las Navas bautizó a un buen número de indios e hizo la fundación a cargo de su Orden. Al mismo año corresponde la elección del sitio en que se levantarían la iglesia y el convento, los cuales se dedicaron a la Asunción de la Virgen, justo diez años después de la llegada de fray Diego de Estremera; es decir, la dedicación se hizo el 15 de agosto de 1551, si hemos de dar crédito a los Anales de Tecamachalco y Quecholac. ${ }^{1}$ Por consiguiente, la edificación tanto de la iglesia como del hoy destruido convento, debe datar de una fecha no muy lejana a 1541. La primitiva iglesia se incendió en 1557 , pero ya para 1561 la actual estaba a punto de concluirse, por lo menos así parecen confirmarlo las noticias de otra fuente indigena: $\operatorname{los}$ Anales de Tecamachalco ${ }^{2}$ en los que se indica que un arco toral se cerraba en ese año. La torre de la iglesia, conforme a una interesantisima lápida, labrada en bajorrelieve, que está en su base, debe haberse construido hacia 1591, fecha que aparece grabada en la citada lápida con caracteres arábigos e indígenas.

Tanto la iglesia como el convento de Tecamachalco, guardan los lineamientos constructivos que les son comunes a un buen número de

1 Anales de México y sus contornos. Compilados por $D$. José Fernando Ramírez. Tomo it. Número 22. Anales de Tecamachalco y Quecholac. "Texto mexicano y traducción del licenciado Faustino Chimalpopoca Galicia. Comienzan en 1520 y terminan en 1558. El licenciado Galicia dice que sacó la copia de un cuaderno que le prestó un vecino de Tlaltelolco." Este interesante documento, en copia manuscrita, perteneció a la biblioteca del historiador José Fernández Ramírez y hoy se encuentra en el Archivo Histórico del Instituto Nacional de Antropología e Historia.

2 Los Anales de Tecamachalco. Crónica local y colonial en idioma náhuall 1530-1590, fueron publicados en 1903 por el doctor Antonio Peñafiel en su Colección de Documentos para la Historia Mexicana. Para los fines de este trabajo, como se verá, son de primera importancia. 
obras edificadas bajo la dirección de los propios religiosos, en esos años en que no abundaban, por cierto, los alarifes calificados. La fábrica del convento hoy luce el triste y romántico espectáculo que ofrecen las ruinas arquitectónicas; algunos vestigios artísticos, regados aquí y allá, nos hablan silenciosamente de pasadas grandezas. Mejor suerte ha corrido la iglesia; su enorme nave, hecha con vigoroso mamposteo, está cerrada con las características bóvedas de nervaduras del siglo xvi; el espacio arquitectónico que se ha creado aqui, modela la grandeza del interior con la sencillez de los volúmenes que encierra.

La decoración escultórica de la iglesia concéntrase, principalmente, en las dos portadas. La mayor es uno de esos curiosos ejemplares, del estilo gótico-isabelino, con que cuenta la arquitectura mexidana del siglo xvi. Sin embargo, es superior la importancia que tiene, en lo decorativo, la portada lateral que es la que corresponde a la llamada Puerta de la Porciúncula de toda iglesia franciscana. En su diseño es tributaria, en buena dosis, del arte mudéjar, interpretado y enriquecido con el espíritu y la técnica del artista indigena que intervino en su construcción. Veamos. En primer lugar se destaca el empleo que se ha hecho de un material que los alarifes indios solían aplicar en sus obras para darles color: el tezontle; el cual se ha aprovechado aquí para cubrir el espacio comprendido entre las vueltas del arco trilobulado y el arrabá. En segundo lugar sobresalen, por su fuerza y carácter, las águilas esculpidas en el bajorrelieve que corre en torno del arco; águilas compañeras de la que aparece en la lápida de la torre y que respiran, aún, el aliento de la gran escultura prehispánica.

A semejanza de otros conventos del siglo xvi, el de Tecamachalco fue un centro importante de cultura, del cual apenas si nos quedan hoy los vestigios documentales; merced a los mismos vamos a intentar formar una relación, para los fines de nuestro trabajo, sobre los frailes que estuvieron en el lugar. Habitaron en la casa conventual de Tecamachalco, lingüistas tan destacados como fray Francisco del Toral, autor, precisamente, de varias obras en lengua popoloca, escritas antes de salir hacia su Obispado de Yucatán; en 1543 estuvo como guardián el ínclito poliglota, fray Andrés de Olmos; fray Alonso de Molina ocupó la guardianía hacia 1558. ${ }^{3}$ Los religiosos citados aparte de ser excelentes entendedores de las lenguas del país, también eran autoridades consumadas en las diversas disciplinas que formaban la cultura humanista

3 Estas noticias provienen de los ya citados Anales de México y sus contornos : los Anales de Tecamachalco, y las confirman la Historia Eclesiástica Indiana de fray Jerónimo de Mendieta y el Teatro Mexicano de fray Agustín de Vetancurt. 
de esa época; junto a ellos habría que anotar a otros ilustres frailes que hicieron del convento de Tecamachalco, un lugar de esmerada cultura; por Vetancurt sabemos que allí dictó unos cursos especiales, sobre Artes y Teología, el célebre franciscano fray Francisco de Bustamante. ${ }^{4}$

La importancia que en la vida civil tuvo Tecamachalco, no fue menor a la que administraban los frailes desde el convento. El pueblo fue asiento de varios caciques indígenas que constantemente Iuchaban entre sí, por la primacía del poder y determinados privilegios reales. Uno de estos caciques, acaso el más inquieto, fue Tomás Gerson de quien los documentos de la época constantemente se ocupan, ya alcanzando el favor de usar hábito de español y portar espada, así como la licencia para andar a caballo con silla y freno, o bien, en un pleito por la posesión de unas tierras de la estancia de San Lucas, que le disputaba el cacique Francisco de Mendoza. ${ }^{\circ}$ Tomás Gerson, que sin duda pertenecía a una de las familias más antiguas y principales de Tecamachalco, fue nombrado en 1591 gobernador del vecino pueblo de Tepeji de la Seda, pueblo que dentro de la economía de la región alcanzó gran importancia. Sin embargo, para el año siguiente, se encuentra en dificultades; se le denunció por los abusos que cometía al sacar indios e indias de Tecamachalco, para que le sirvieran en Tepeji. ${ }^{6}$

Señores de Tecamachalco lo fueron también los condes del Valle de Orizaba. Melchora de Aberrucia, viuda del conquistador Alonso Valiente, poseía una encomienda en el pueblo; en marzo de 1563 se casó con Rodrigo de Vivero y Velasco. Su primogénito llegó a ser el primer Conde del Valle de Orizaba y Señor de Tecamachalco. Los condes fueron, por lo tanto, patrones del convento franciscano, “... las armas de los condes del Valle de Orizaba, están pintadas en el convento y en la celda guardianal (sic) el retrato del dicho señor don Rodrigo..." Estas noticias

4 En su Teatro Mexicano. T. Iv. Colección Chimalistac. José Porrúa Turanzas, editor. Madrid, 1961, p. 158.

5 El cacicazgo de Francisco de Mendoza supervivió, por lo menos, hasta el siglo xrir. Guillermo S. Fernández de Recas publicó una petición de reconocimiento que hizo en 1679, un descendiente de este cacique. Vide: Cacicazgos y nobiliario indigena de la Nueva España. Biblioteca Nacional de México. Instituto Bibliográfico Mexicano. Méxiço, 1961.

6 Todas estas noticias proceden del Ramo de Indios del Archivo General de la Nación, las dio a conocer, en la recopilación que hizo, el profesor Luis Chávez Orozco. Véase: fndice del Ramo de Indios del $A$. G. de la $N$. Ediciones especiales del Insti. tuto Indigenista Interamericano con el A. C. de la $\mathbf{N}$. Secretaria de Gobemación. Tomo 1, 15j4 a 1590. México, 19:31. Tomo n, 1590 a 1597. Mćxico, 1953. 
nos las proporciona un manuscrito inédito de fray Francisco Antonio de la Rosa, quien más adelante nos dice que el primer conde, don Rodrigo Vivero Aberrucia, tenia "en la pared lateral del presbiterio, su estatua de bulto, que representa a su persona..."; ${ }^{7}$ es decir, que en el presbiterio de la iglesia y sobre la tumba del primer conde, se encontraba su escultura funeraria, tal como correspondía a su rango y a Ia supervivencia de una costumbre medieval.

La iglesia franciscana de Tecamachalco, independientemente de sus valores arquitectónicos y escultóricos, ocupa un lugar importante en la historia del arte virreinal mexicano, merced a las pinturas que conserva en la bóveda del sotocoro, inspiradas en escenas del Antiguo Testamento. Estas singulares pinturas fueron dadas a conocer desde 1932, por don Manuel Toussaint, ${ }^{8}$ quien las identificó como salidas del pincel de Juan Gerson, gracias a las noticias que registran, de los años 1561 y 62, los ya citados Anales de Tecamachalco. Las noticias principales, escritas en lengua náhuatl, rezan así: No yhquac motlalli tecololli yn icatqui juan gerson tlahcuillo, y en su traducción al castellano: También entonces se colocó el arco, fue Juan Gerson el pintor. Las referencias que se dan en 1562 son muy claras respecto al coro: Nican yn opeuh yan ihcuiloua coro, cuicayan, no nican. Entonces comenzó a pintarse el coro, lugar del canto, también entonces. ${ }^{9}$ Las fechas que ofrecen los Anales, se confirman con las inscripciones pintadas en los cuatro medallones que muestran los símbolos de los evangelistas; el de San Juan leza así: S. IVAN EVANGELISTA I. MAIVS 1562 ANOS IPAN OMO. CHIVIN. Las palabras en lengua náhuatl vienen a significar en él se hizo; o sea, que en 1562 se hicieron estas pinturas.

No obstante que se conoce el nombre de su autor, las pinturas de Tecamachalco han representado en la historia de la pintura de la Nueva España, un problema de investigación estética que mucho ha distado de ser solucionado. El problema ha girado en torno a la nacionalidad deI

i Testimonio auténtico de varias noticias genealógicas y cronoldgicas de los llustres Señores Condes del Valle de Orizaba..., por fray Francisco Antonio de la Rosa. 13 de diciembre de 1774 .

8 "Pinturas coloniales en Tecamachalco". Revista de Revistas. México, octubre 9 de 1932. El artículo fue reproducido bajo el título "Pinturas Coloniales. Teca machalco", en Mapa. Revista de Turismo. México, mayo de 1934.

9 Aprovecho aquí las traducciones que hizo del náhuatl el doctor Miguel León Portilla, para la Introducción que escribió Elisa Vargas Lugo en su edición de la Historia de la Pintura en Puebla, de Francisco Pérez Salazar. Instituto de Investigacioncs Estéticas. Estudios y Fuentes del Arte en México. xir. México, 1963, pp. 16-17. 
pintor, en el estilo de su expresión artística y en las fuentes donde se inspiró.

Para don Manuel Toussaint, Juan Gerson fue un pintor flamenco que antes de pasar al Nuevo Mundo, había recorrido Italia; de allí provenía para Toussaint, precisamente, el colorido empleado por Gerson, si bien éste no habia olvidado las características formales del arte de su país. ${ }^{10}$ Los juicios vertidos por Toussaint corrieron con gran fortuna, pues quien más, quien menos, repitió lo del origen flamenco y estilo italianizante, en medio de otras observaciones que por desgracia no alcanzaron mayor profundidad. Así, por ejemplo, Agustín Velázquez Chávez, admitió que en las pinturas había algo del "dibujo de los códices indios". ${ }^{11}$ Casi por idéntica pista anduvo don Francisco Pérez Salazar, al suponer que Juan Gerson era natural de Tecamachalco, es decir, que era indio y que el nombre y apellido los había adquirido por apropiación. ${ }^{12}$ El origen indigena fue negado enfáticamente por George Kubler, quien encontró en cambio, que tanto el nombre como el estilo artístico, son francamente norte-europeos; se volvió pues, a lo flamenco; pero sin hacer ya alusión alguna a lo italiano, respecto a los colores preferidos por el pintor. ${ }^{13}$ Sin embargo, la mayor aportación que Kubler hizo, no estuvo en los juicios anteriores sino en la erudita investigación que realizó tendiente a identificar las fuentes o grabados utilizados por Juan Gerson, para sus pinturas del sotocoro. Con excelente criterio supuso que las láminas debieron pertenecer a alguna Biblia, de la cual dependió completamente el artista. Por otra parte, Kubler hizo por primera vez, la identificación de los libros de la Biblia de los que salieron los temas. Para este distinguido historiador, la mayor parte de los pasajes interpretados en Tecamachalco, provenían de las ilustraciones de la Biblia de Wittemberg, impresa en 1522, o del taller de alguno de los imitadores que pronto tuvieron los grabados de esa célebre edición. No escapó a su percepción estética el que las pinturas se hubiesen copiado, incluso, de cualquier versión inspirada en las famosas series del Apocalipsis de Durero. De las veintiocho pinturas que se encuen-

10 Vide: "Pinturas coloniales en Tecamachalco", publicado en Revista de Revistas. La pintura en México durante el siglo XVI. Enciclopedia llustrada Mexicana. México, 1936, p. 43. "Tecamachalco y las pinturas de Juan Gerson", en Paseos Coloniales. Segunda edición. Instituto de Investigaciones Estéticas. México, 1962, pp. 116-20.

11 Tres Siglos de Pintura Colonial Mexicana. Editorial Polis. México, 1939, p. 177. 12 Véase su Historia de la Pintura en Puebla, p. 51.

13 Mexian Architecture of the Sixteenth Century. Yale University Press. New Haven, 1948. T. II, pp. $367-68$, 
tran en la bóveda del sotocoro, Kubler logró identificar que las que representan El Altar de Ariel y El Templo de Salomón, figs. 14 y 15, tenían su origen indudable en los famosos Iconos que en 1547 grabó Hans Holbein. Si bien es verdad que las investigaciones de George Kubler no le llevaron hasta la fuente exacta que utilizó Juan Gerson, no menos cierto es que muchas de sus observaciones fueron de positivo interés para entender el origen de las pinturas, pese a su desdén para ver lo que rotundamente negó: la presencia de un artista indio como autor de las mismas.

A la aportación crítica hecha por Kubler, dentro del proceso para definir la personalidad de Juan Gerson, se sumó el juicio del historiador español Diego Angulo fñiguez, el cual, tras de señalar la singularidad de los temas bíblicos dentro del arte español, agregó que por el estilo de las pinturas, éstas le hacían pensar más bien, "en un pintor provinciano (español) de los días de la conquista"; siguiendo la corriente iniciada por Toussaint, Angulo no desdeñó la posibilidad de que Gerson hubise sido un artista flamenco, máxime cuando el arcaísmo de las formas así se lo indicaba y coincidiendo con Kubler, advirtió la influencia de los grabados de Durero, sobre todo el que representa a Los Cuatro Jinetes del Apocalipsis, tan cercano, por su composición, a la pintura del mismo tema. ${ }^{14}$ Otros autores han repetido, sin mayor reflexión, lo del origen flamenco del pintor y su italianismo pictórico. En fecha reciente, tanto Jorge Gurria Lacroix, como Elisa Vargas Lugo, insistieron, de nueva cuenta, en el origen indígena de Juan Gerson. Vargas Lugo, con buen juicio, asentó que se trataba de un indio al que dieron unas láminas a copiar para sus pinturas, en las cuales depositó unas "buenas dosis de originalidad". 15 Con entera certidumbre Gurría Lacroix, puso de manifiesto la identidad de Juan Gerson "yndio Principal de Tecamachalco", mediante un documento que localizó en el Archivo General de la Nación, la investigadora Rosa Camelo. ${ }^{16}$ Con esta última aportación y los datos contenidos en los Anales de Tecamachalco, no existe duda alguna respecto a la nacionalidad del pintor.

14 Historia del Arte Hispanoamericano. T. II. Salvat Editores. Barcelona, 1950, pp. 370-71.

15 En su prólogo para la edición de la Historia de la Pintura en Puebla, de Pérez Salazar, véase p. 18.

16 "Las pinturas del socoro de Tecamachalco". Boletin del I.N.A.H. Núm. 11, marzo de 1963, p. 21. Véase también el núm. 12 de este Boletin: "Las pinturas de Juan Gerson en Tecamachalco", por Constantino Reyes Valerio. Jorge Gurría Lacroix, Rosa Camelo y Constantino Reyes V., preparan una extensa monografía sobre Tecamachalco. 
Asi pues, nuestro artista debió pertenecer a una de las principales familias indigenas de Tecamachalco; posiblemente fue pariente muy cercano, hermano tal vez, del cacique don Tomás Gerson de quien atrás nos ocupamos; pues no deja de ser significativo que aparte del apellido, ambos recibieran el 4 de febrero de 1592, idéntica merced que les otorgaba el virrey don Luis de Velasco, hijo. El favor dado al pintor dice: "El dicho día se dió otra licencia a don Juan Gerson, indio principal de Tecamachalco, para andar en un caballo con silla y freno por el tiempo que fuere la voluntad de su magestad y la de su alteza... y así mismo para que andando con el hábito de español, pueda traer espada y daga en partes y a horas permitidas." En cuanto al nombre de Juan Gerson, éste con toda seguridad le fue impuesto por alguno de los frailes residentes en el convento; quizá el mismo que le encargó las pinturas, para distinguirlo y honrarlo, le dio el nombre del famoso teólogo francés, Juan Gerson. ${ }^{17}$ Como es bien sabido éste no fue el único caso en que a un indio notable se le diera un nombre célebre; precisamente en el vecino pueblo de Quecholac, figura por esos años un cacique que lleva el nombre del Doctor Angélico: Tomás de Aquino inada menos! 18

Un estudio detenido y un cuidadoso análisis de las formas, fue lo que faltó a los historiadores que se ocuparon de las pinturas del sotocoro de Tecamachalco, antes de que se descubriera el manuscrito que puso en claro el origen indio de Juan Gerson; no obstante las palabras escritas en lengua náhuatl en los medallones de los evangelistas, nadie dio importancia plena a ello para certificar la identidad del artista. Por otra parte, en el análisis mismo de las formas de su expresión estética estaba bien definida, ante los ojos de los críticos, su personalidad. En efecto, en las pinturas existen ciertos elementos derivados del arte indígena y éstos son tan patentes, como lo son en los relieves de las águilas de que anteriormente se ha hablado. Por ejemplo, de franca

17 E1 nombre propio del teólogo, fue Juan Le Charlier. Nació en la aldea de Gerson, antigua diócesis de Reims, el 14 de diciembre de 1363; de su pueblo tomó el patronímico que le inmortalizó. Murió en Lyon, donde se publicó más tarde buena parte de sus obras, el 12 de julio de 1429. Los tratados del doctor christianissimus o doctor consolatorius, como le llamaban teólogos y misticos, fueron conocidos en la Nueva España; el ilustre don fray Juan de Zumárraga hizo imprimir en México, en 1544, su Tripartito..., según la edición toledana de 1526. Véase la Bibliografía Mexicana del siglo XVI, de Joaquín García Icazbalceta. Nueva edición por Agustín Millares Carlo. México, F.C.E. 1954, pp. 64-65.

18 Tomás de Aquino aparece como alcalde de 1570 a 1580 , según los Anales de Quecholac. 
inspiración indigena, en su diseño, es la parte central de la bóveda de crucería; en torno al escudo franciscano se pintaron con colores, bermellón y blanco, unas grandes plumas, creando con ello una imagen muy cercana de lo que fueran los viejos chimalis o rodelas, de los guerreros pre-hispánicos, fig. -3. Las raíces indigenas se acusan, de manera notable, en las figuras de las aves; así en la simbólica águila del evangelista San Juan, fig. 4; como en la delicada garza que vuela con otros pájaros, sobre la fabulosa Arca de Noé, fig. 9. Con ese realismo que sólo a un artista de su mundo le era dado interpretar, Gerson pintó las serpientes que aparecen en las colas de las langostas, según el conocido pasaje bíblico; y asimismo en las colas de los monstruos que montan los jinetes que acompañan a los cuatro ángeles del abismo, ...pues sus colas son semejantes a serpientes, y tienen cabezas, $y$ con éstas hieren. Apocalipsis, Cap. Ix, vers. 19, véanse las figs. 31 y 33.

Un buen índice que no se tuvo presente para redondear la identidad indigena de Juan Gerson, lo ofrecían los colores que manejó en su paleta; éstos son, ni más ni menos, los mismos que aparecen en las pinturas de los códices prehispánicos y aún en aquellos que los españoles ordenaron hacer a los indios, recién concluida la conquista. Además, es lógico pensar que en los años en que Gerson trabajaba, los ejemplos de pintura europea que los frailes podían presentar a sus ojos no eran numerosos; no sucedía así con las estampas, pues éstas estaban contenidas en los libros, no había más que copiarlas y aplicarles el color y en esto último sí que existía aquí una larga tradición. Así pues, Juan Gerson trabajó sobre los diseños lineales que le ofrecian los grabados y el colorido lo aplicó acorde a su sensibilidad, de allí ese carácter planigráfico que se advierte en algunas de las pinturas. Los colores de la paleta del tlacuilo Juan Gerson, son los fundamentales de la pintura prehispánica: una gama de rojos, amarillo ocre, sepia, azul hasta llegar al verde, el blanco como fondo y el negro para delinear contornos. El dibujo con que trazó las figuras, corre con firmeza y la delimitación que hay entre los colores, recuerda vivamente la técnica prehispánica. No en balde el pueblo de Tecamachalco queda comprendido dentro de la región Mixteca-Poblana, de la cual proceden los hermosos códices del Grupo Borgia, así como los Mixtecos. Es por ello que fueron muy certeras las observaciones de Agustín Velázquez Chávez, cuando declaró que las pinturas del sotocoro, le recordaban las de los códices y ésto es posible constatarlo, sobre todo, con las aves que vuelan sobre el Arca de Noé, así como en el águila simbólica de San Juan, tan cercana de las que aparecen, por ejemplo, en las hojas del Códice Nuttall. Una compara- 


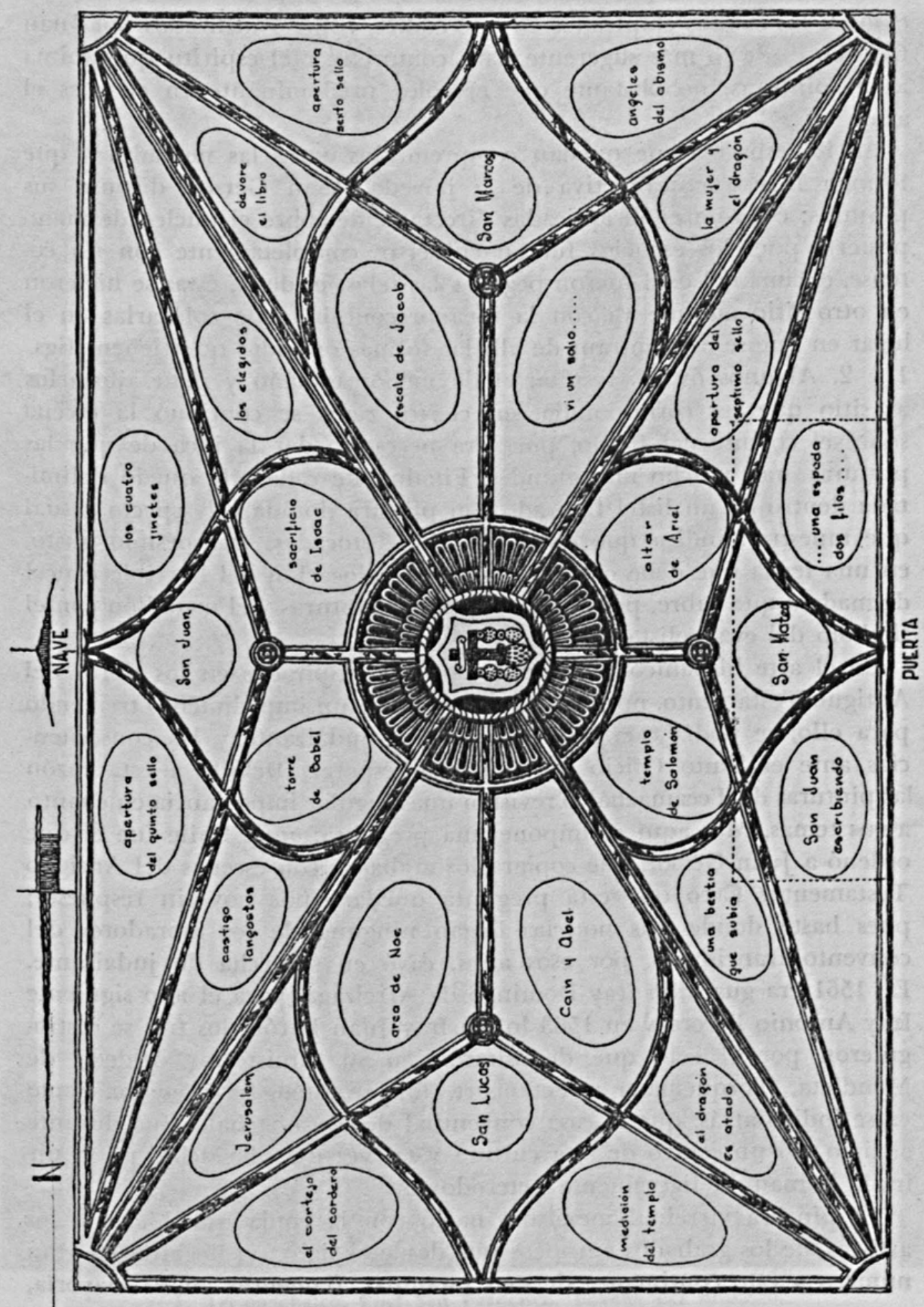


ción de los colores empleados en este códice, con los utilizados por Juan Gerson, es de lo más sugerente para comprender el espíritu que anima a sus pinturas, no obstante que el color predominante en ellas es el azul.

En los espacios que quedan comprendidos entre las nervaduras que forman la estructura activa de la bóveda, Juan Gerson dispuso sus pinturas; éstas no están aplicadas directamente sobre el núcleo de mampostería pues los espacios fueron cubiertos completamente con un cotense, encima del cual fueron pegadas las telas; es decir, éstas se hicieron en otro sitio aunque ya con la idea preconcebida de colocarlas en el lugar en que se encuentran; de allí las formas ovaladas que tienen; figs. 1 y 2. Algunos óvalos resultaron de menor tamaño y para ajustarlos al sitio que les correspondia, en ciertos casos se continuó la escena sobre el cotense clel fondo, pues era necesario dar la idea de que las pinturas eran mucho más grandes. Finalmente cada tela quedó delimitada dentro de un listel figurado con pintura dorada. El aspecto actual que muestran indica que éstas han sido retocadas, con pésimo gusto, en una fecha que debe corresponder a la colocación del horrible cancel de madera que cubre, por cierto, dos de las pinturas y el medallón con el símbolo del evangelista San Mateo.

En el arte hispánico las representaciones inspiradas en los libros del Antiguo Testamento, no son frecuentes; había un impedimento tremendo para ello, se podía caer bajo sospecha de judaizante y las consecuencias ante el Santo Oficio no se hacian esperar. Debido a esta razón las pinturas de Tecamachalco revisten una singular importancia en cuanto a sus temas. Mas aquí se impone una pregunta: ¿qué fraile fue el que ordenó a Juan Gerson que copiara los grabados con escenas del Antiguo Testamento? Creo que esta pregunta quedará por hoy sin respuesta; pues hasta donde mis noticias llegan ninguno de los moradores del convento franciscano, por esos años, cayó en sospecha de judaizante. En 1561 era guardián fray Domingo de Arreizaga, para el año siguiente fray Antonio Parero y en $\mathbf{1 5 6 3}$ lo era fray Juan Barón, los tres se distinguieron por el celo que depositaron en su ministerio, al decir de Mendieta, Torquemada y Vetancurt. Empero, téngase presente, como ya se indicó atrás, que la casa conventual de Tecamachalco fue durante el siglo xvi un centro de alta cultura y tal vez por ella debió pasar un fraile humanista ligeramente heterodoxo.

La pintura virreinal mexicana nació con la copia que hicieron los artistas, de los grabados europeos que desde el siglo xvi llegaron en gran número a este continente; de esas estampas, flamencas en su mayoría, 


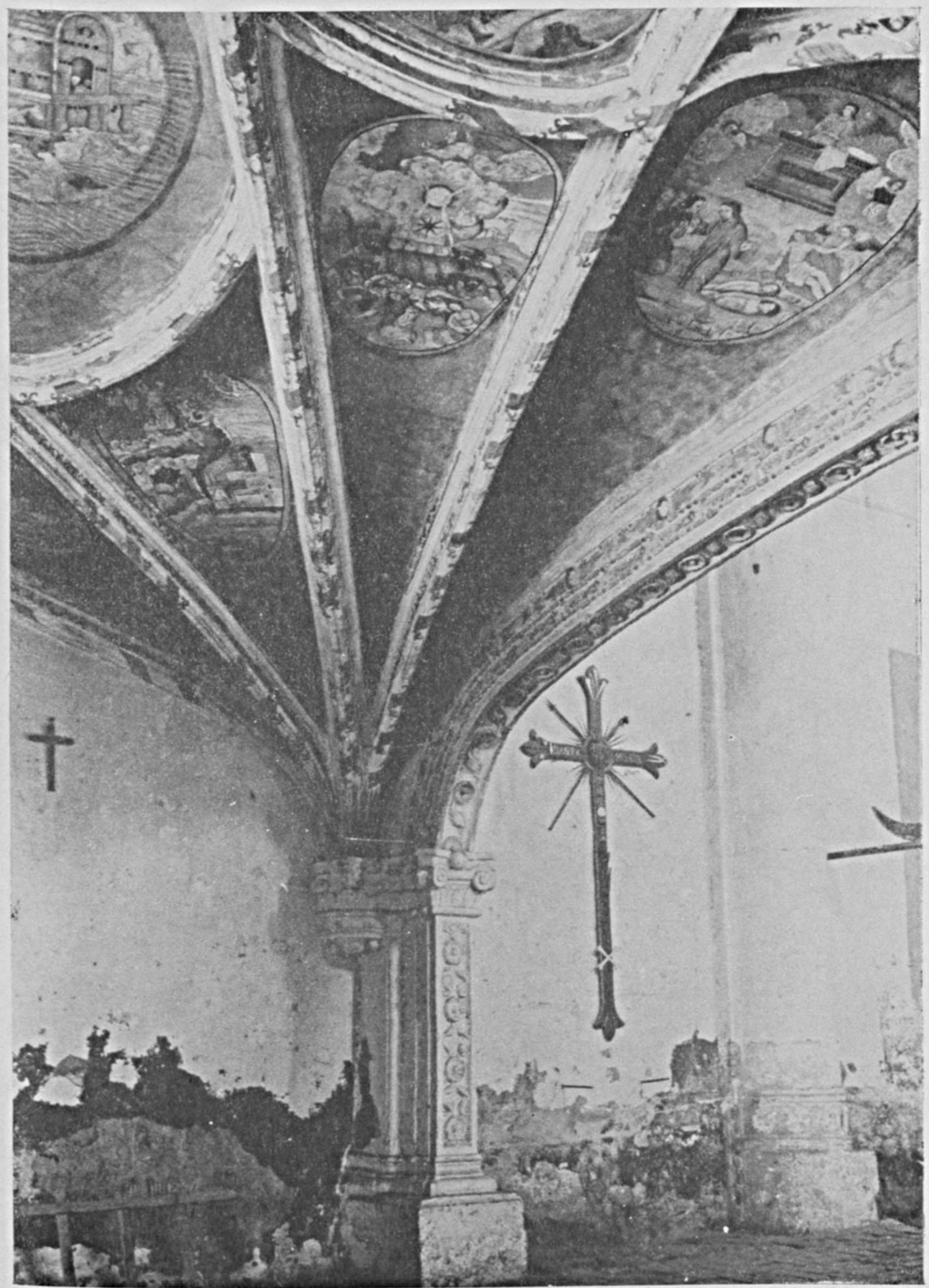

1. Tecamachalco, Pue. San Francisco. Bóveda del sotocoro. 


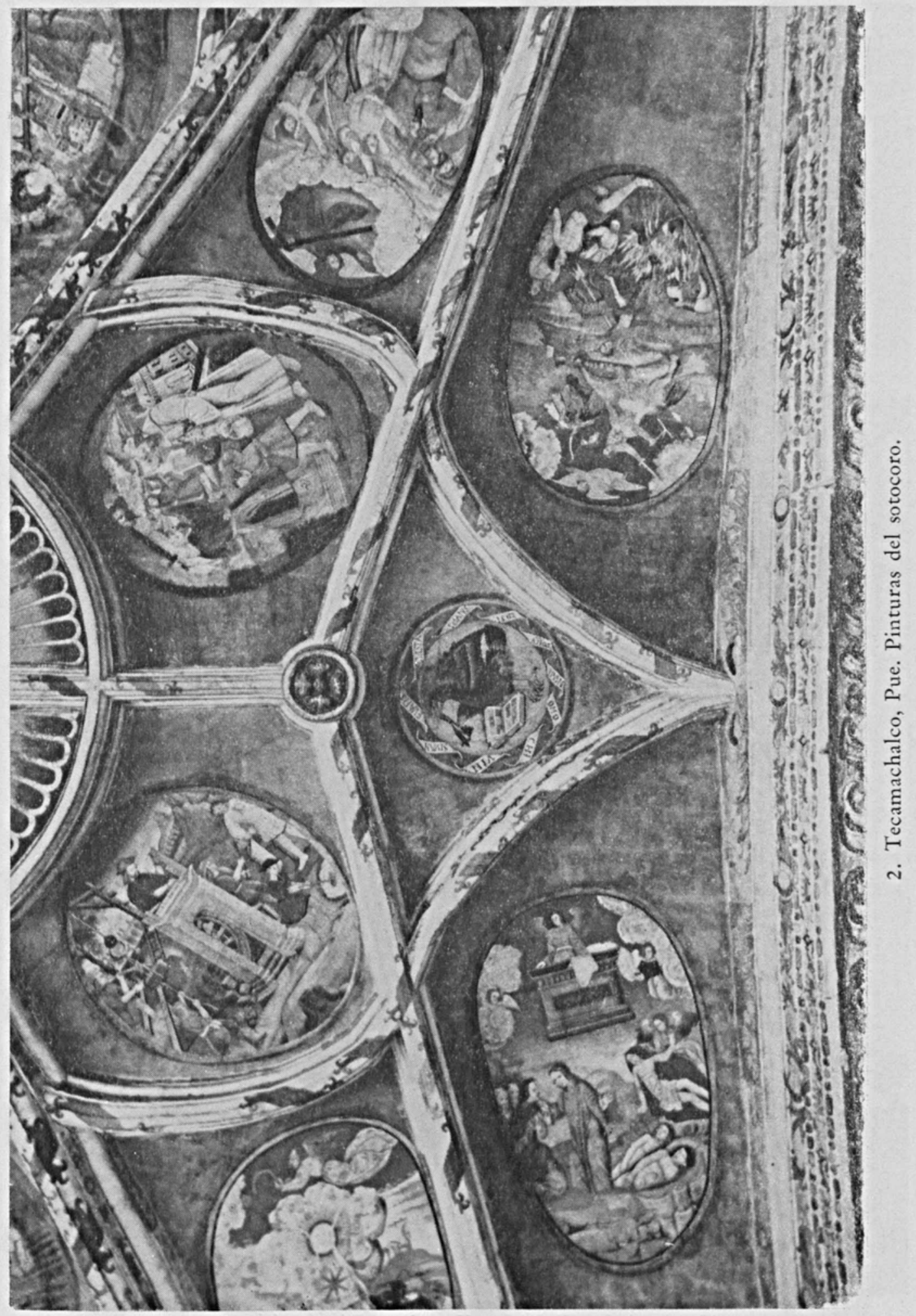


DOI: http://dx.doi.org/10.22201/iie.18703062e.1964.33.774

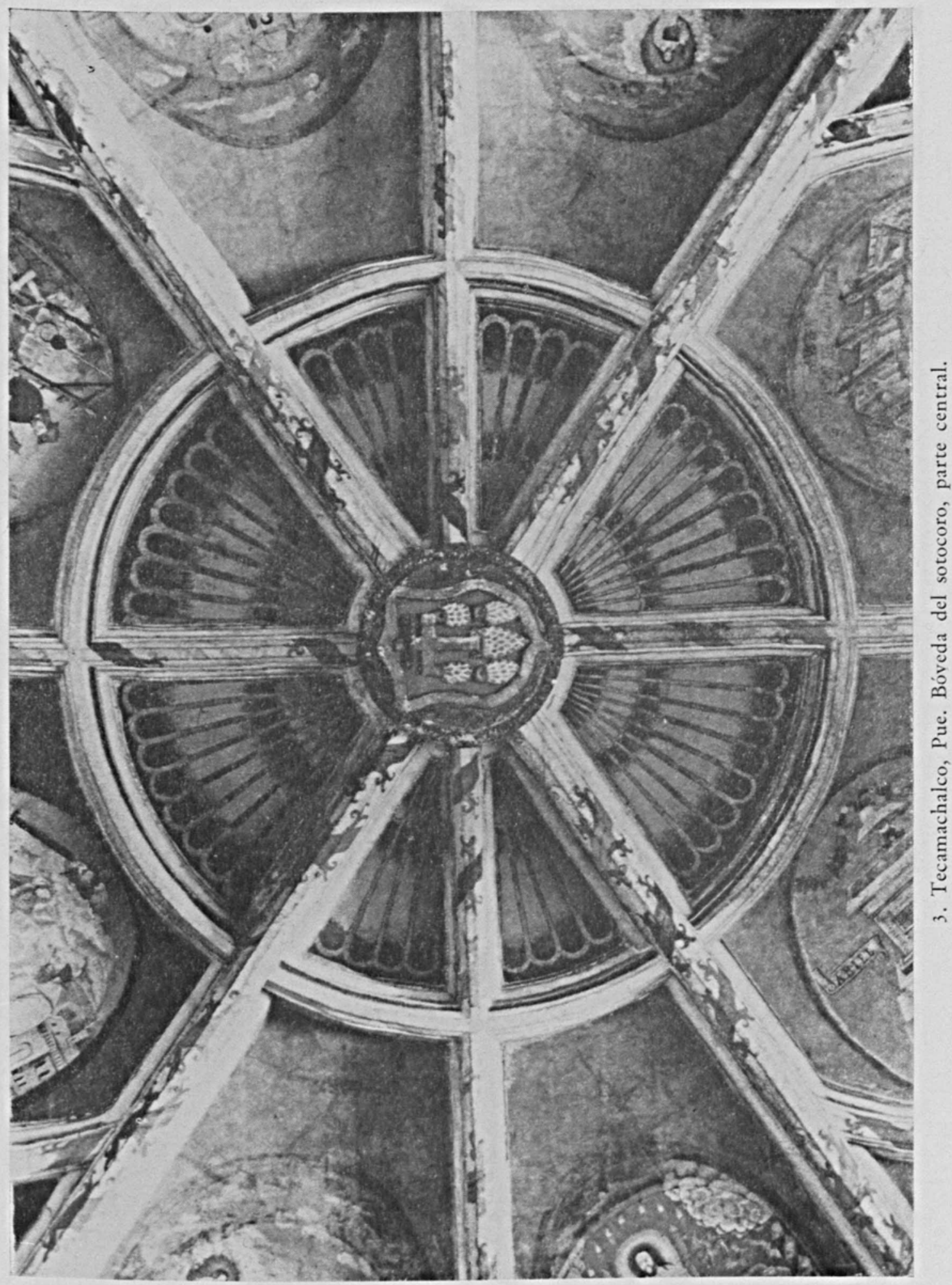




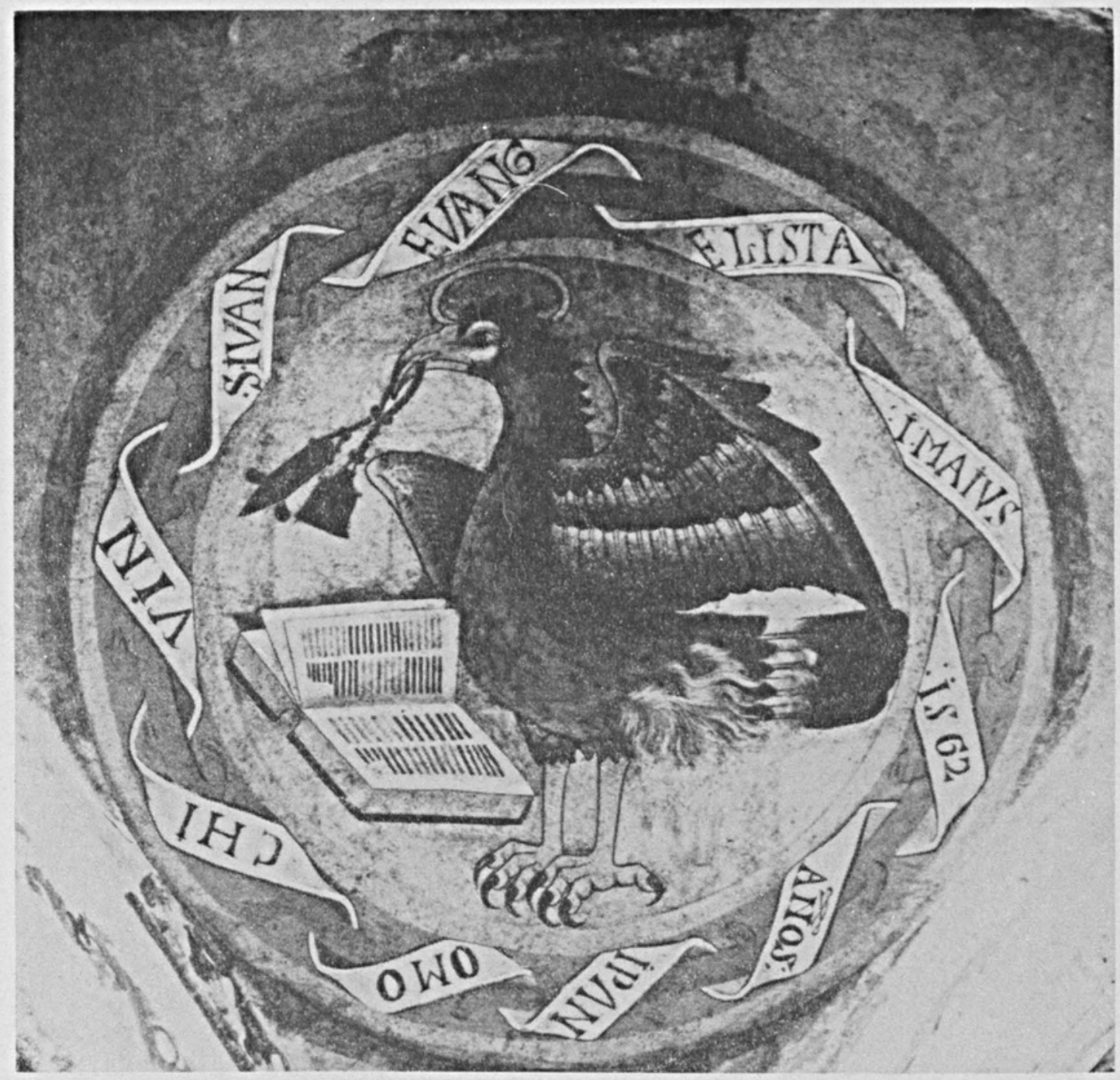

4. Medallón con el símbolo de San Juan Evangelista. 


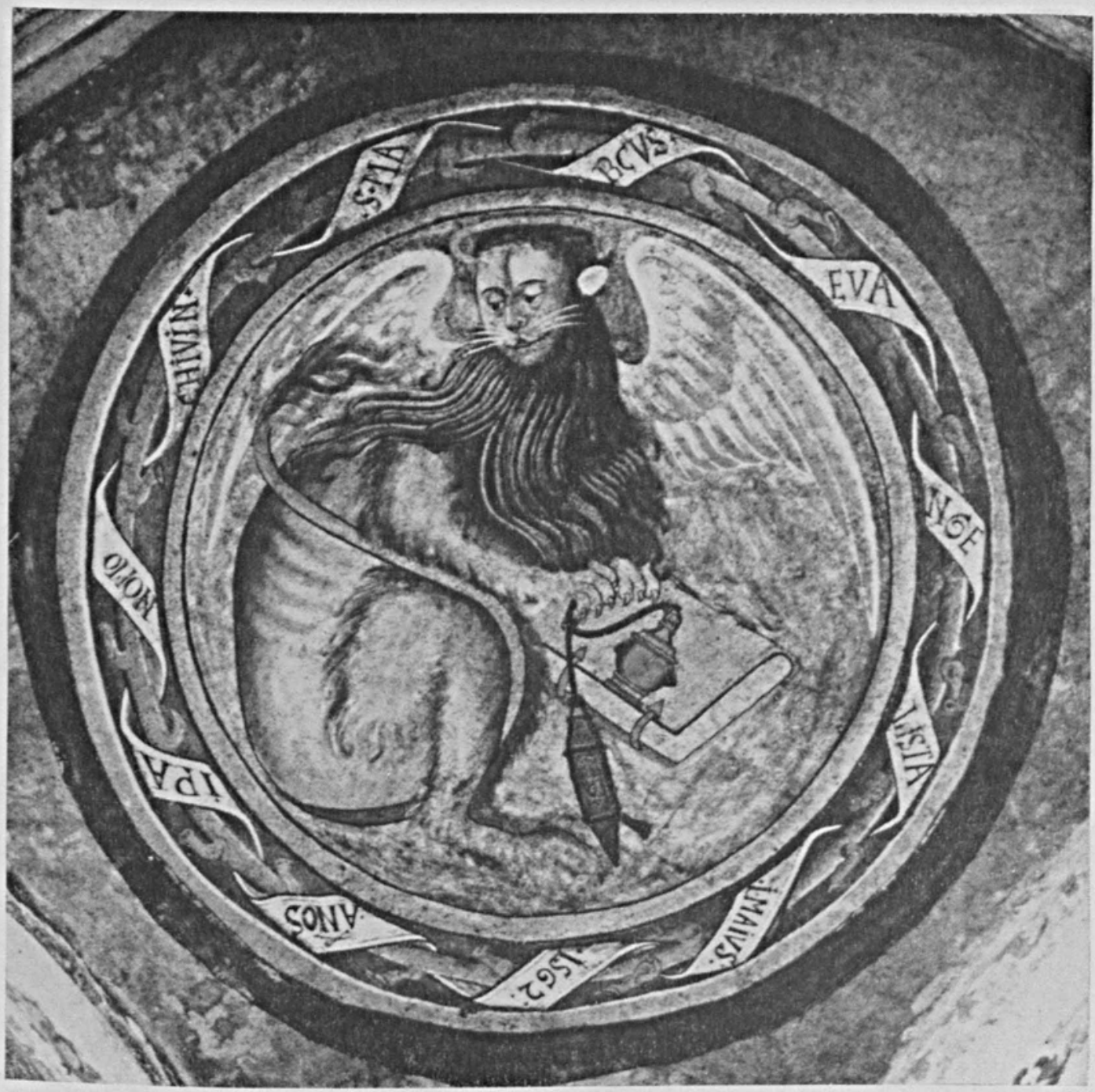

5. Medallón con el símbolo de San Marcos. 
DOI: http://dx.doi.org/10.22201/iie.18703062e.1964.33.774

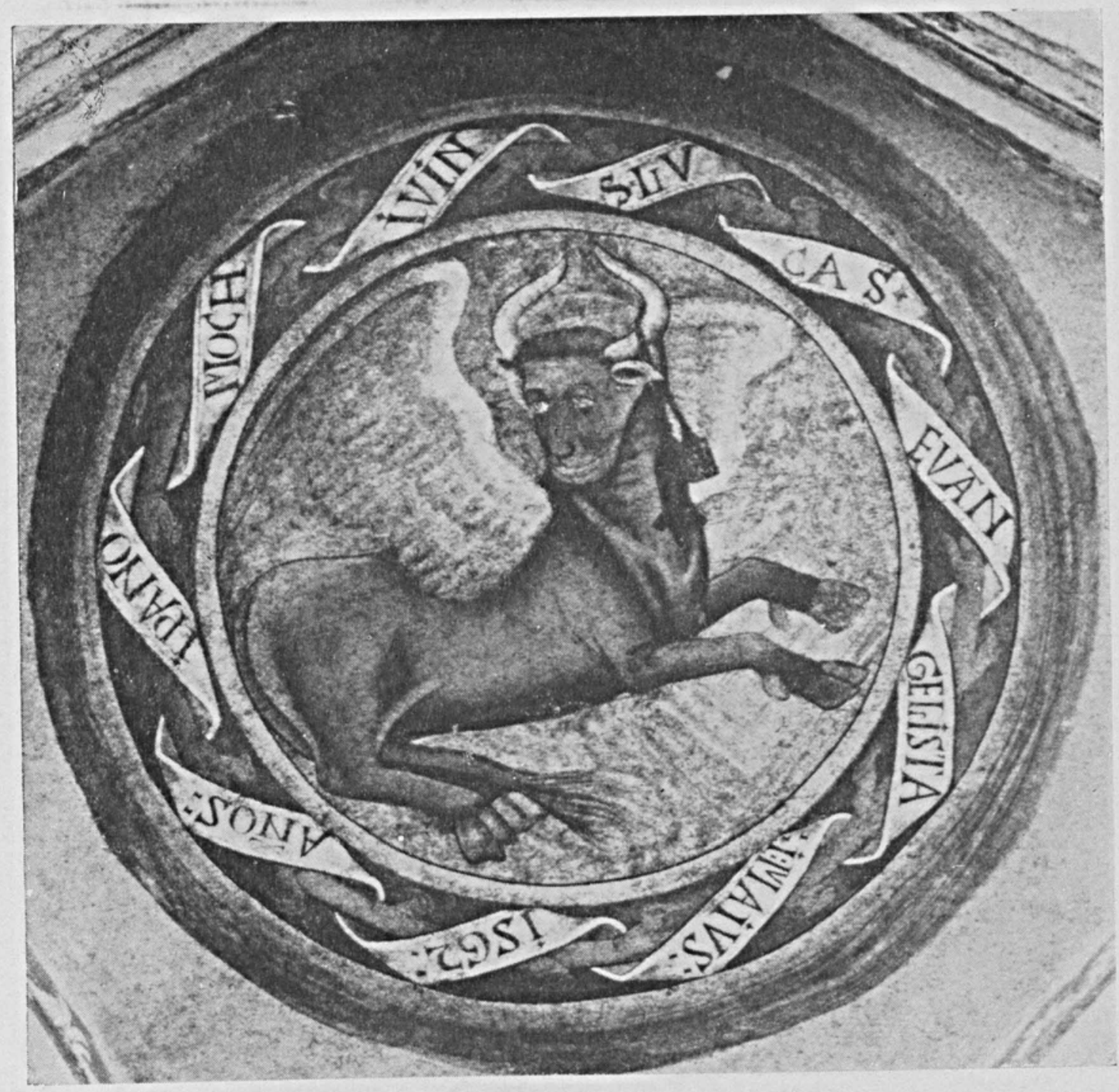

6. Medallón con el símbolo de San Lucas. 
DOI: http://dx.doi.org/10.22201/iie.18703062e.1964.33.774

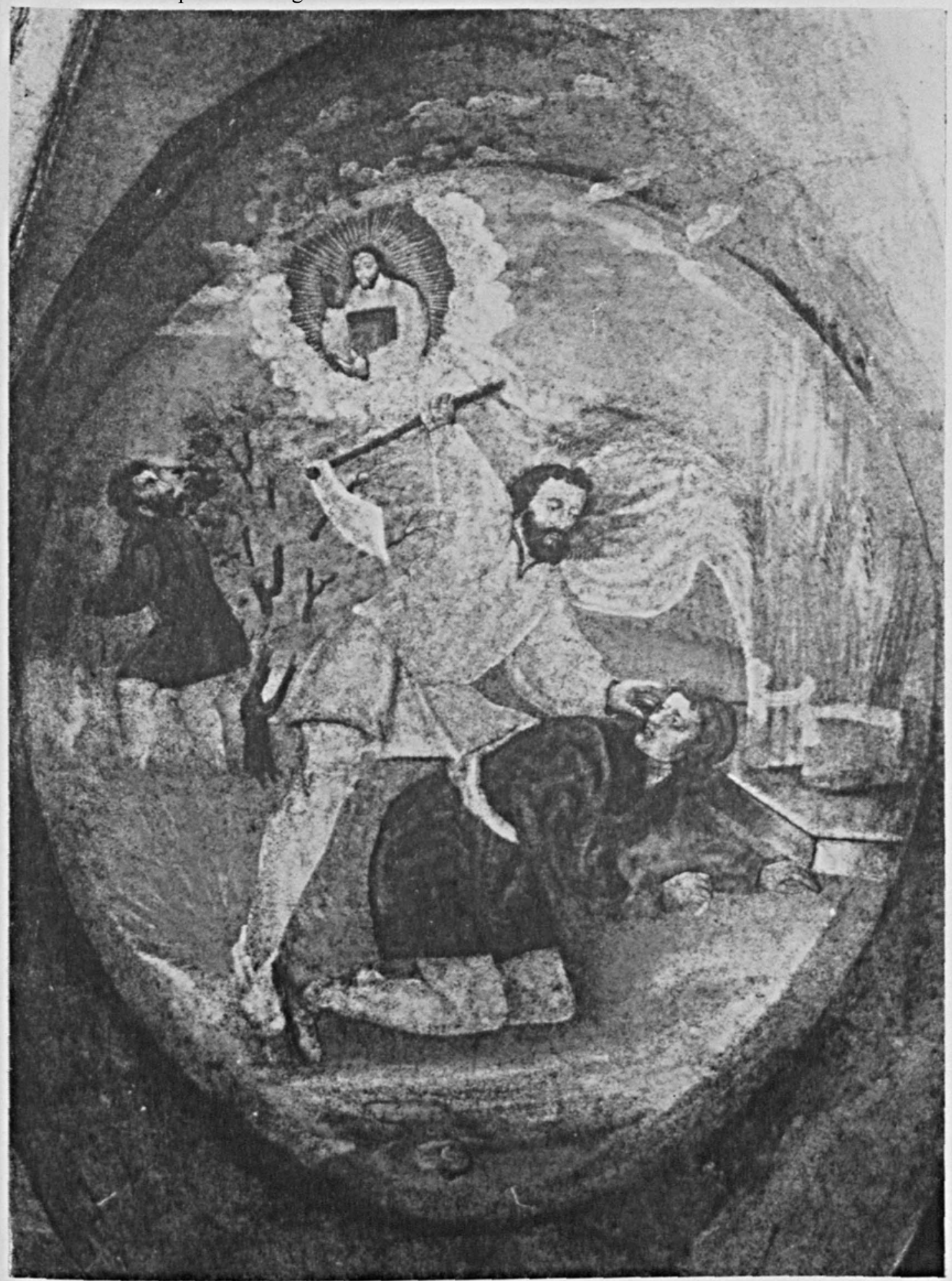

7. Génesis, Cap. Iv, vers. 8, 15, Cain y Abel. 
DOI: http://dx.doi.org/10.22201/iie.18703062e.1964.33.774

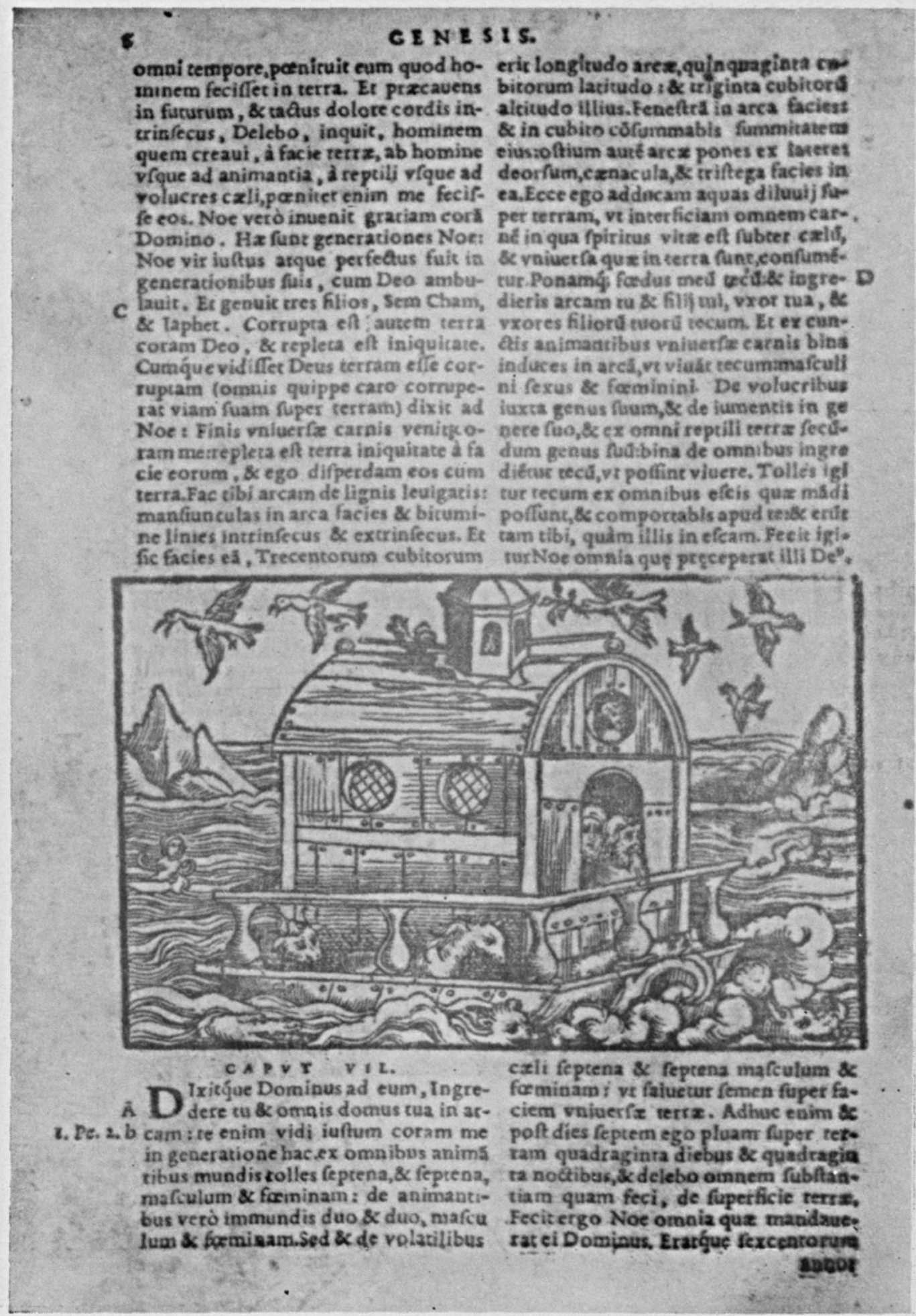

8. Génesis, Cap. vIII, vers. 6,8 . 
DOI: http://dx.doi.org/10.22201/iie.18703062e.1964.33.774

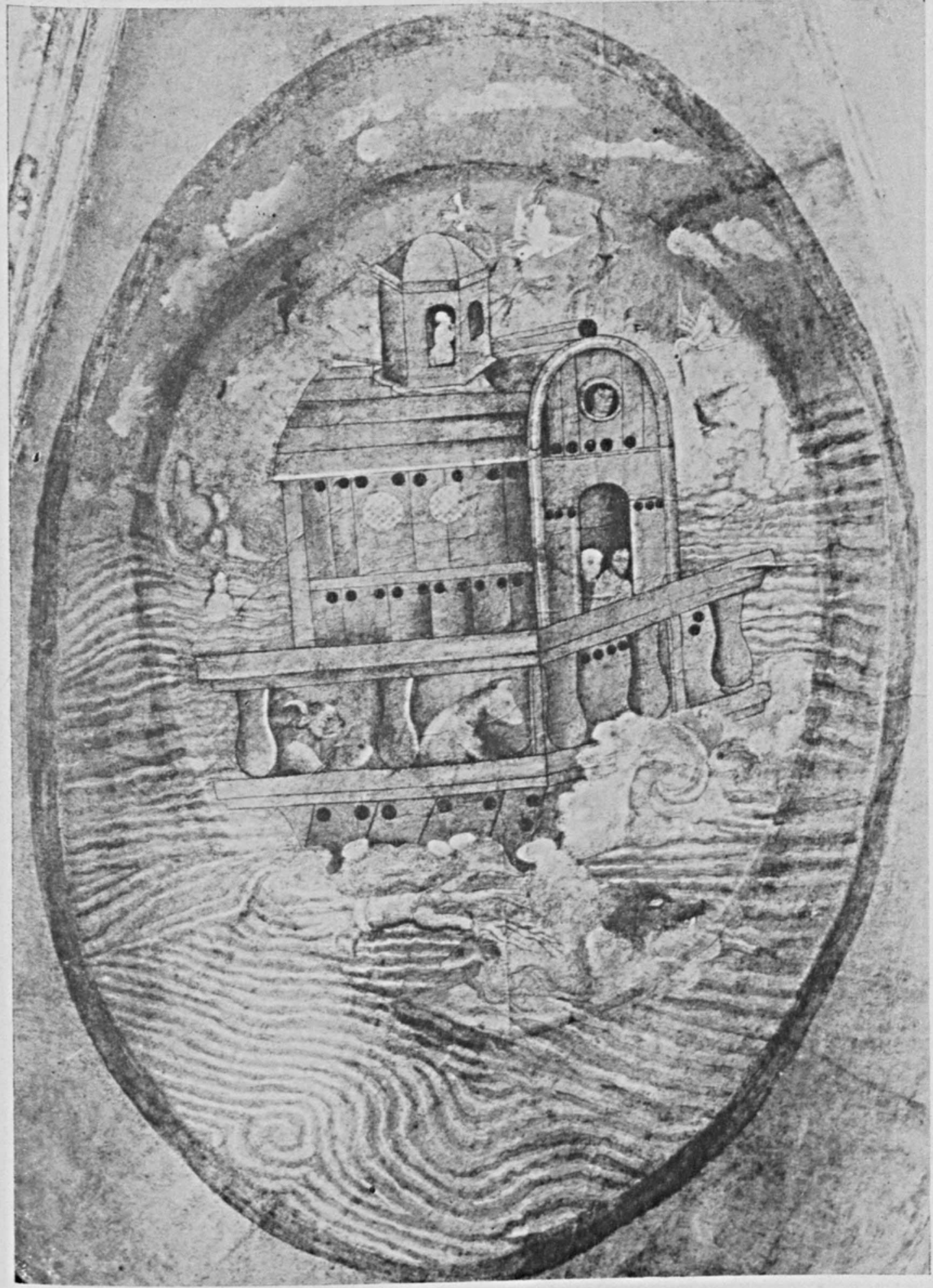

9. El Arca de Noé. 


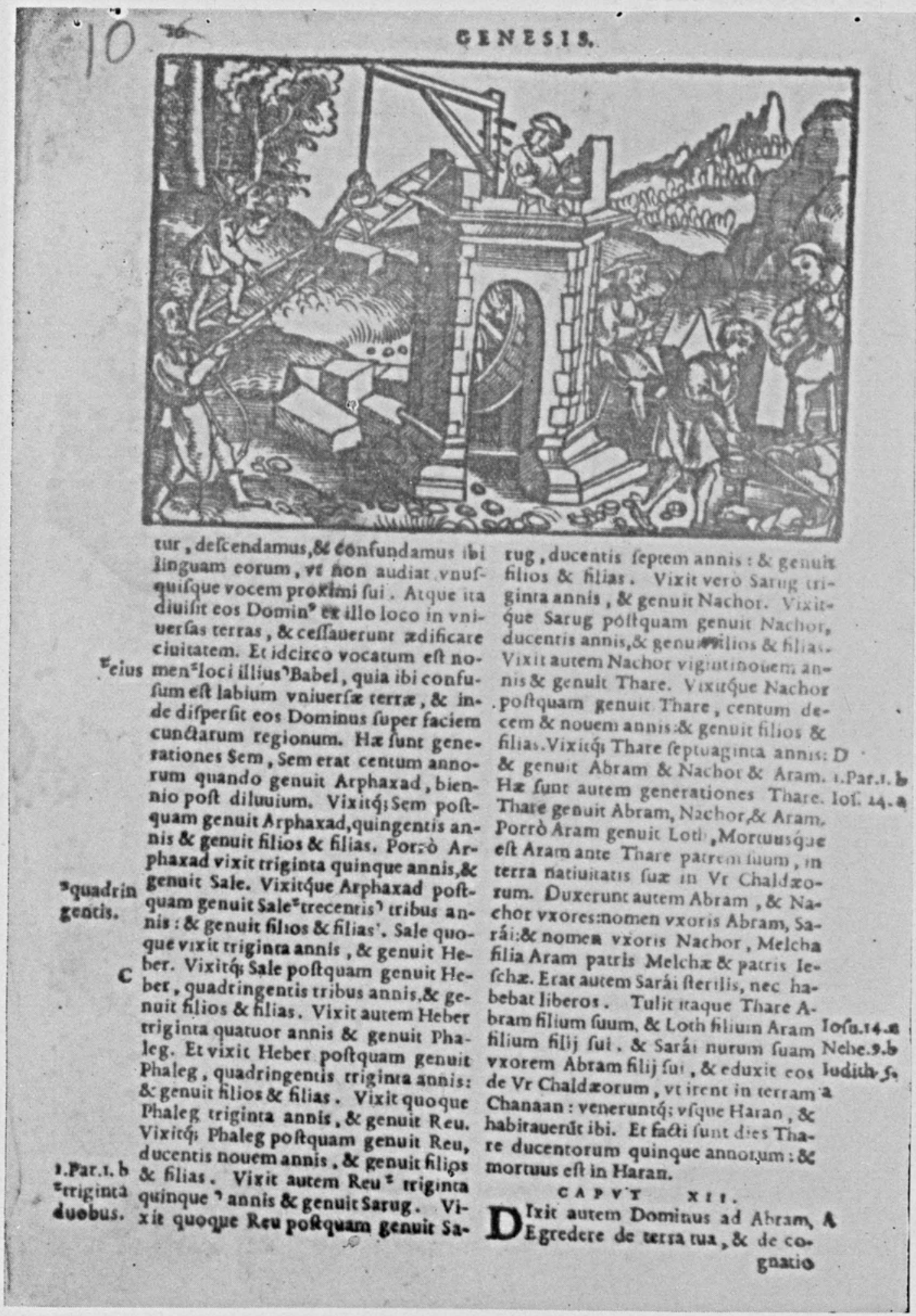

10. Génesis, Cap. Ix, vers. 4. 


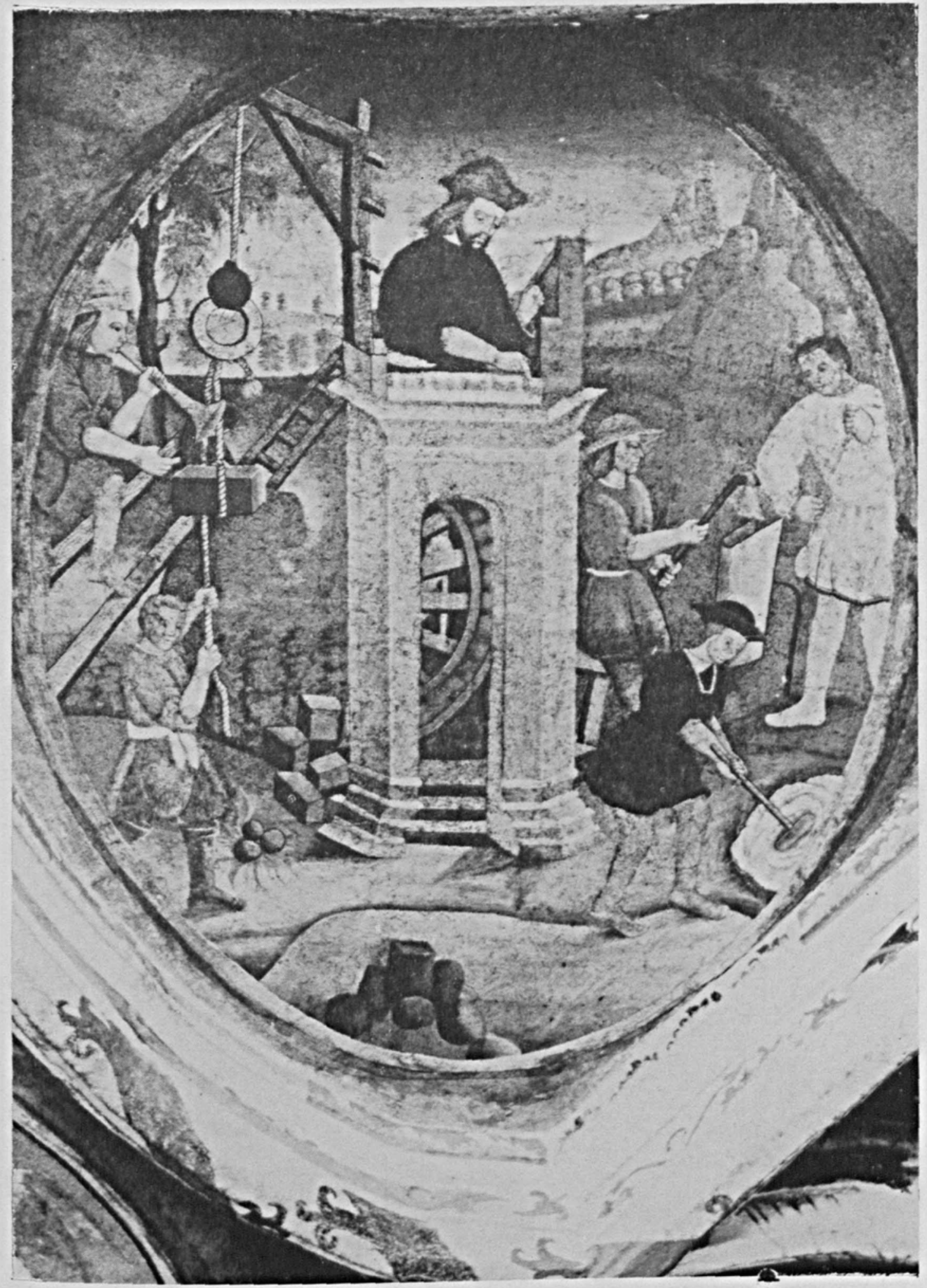

11. La torre de Babel. 
DOI: http://dx.doi.org/10.22201/iie.18703062e.1964.33.774

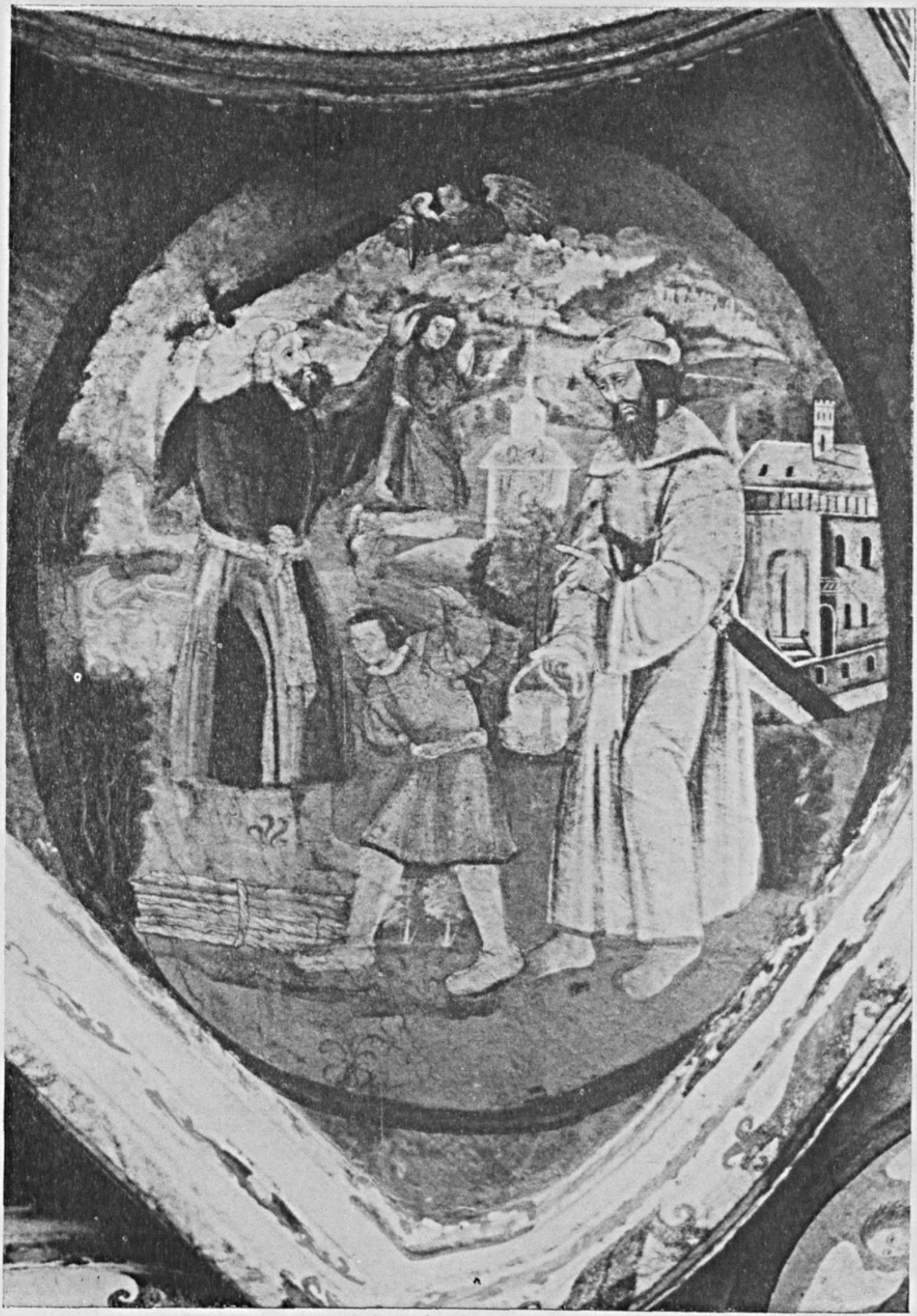

12. Génesis, Cap. xxII, vers. 6, 12. El Sacrificio de Isaac. 


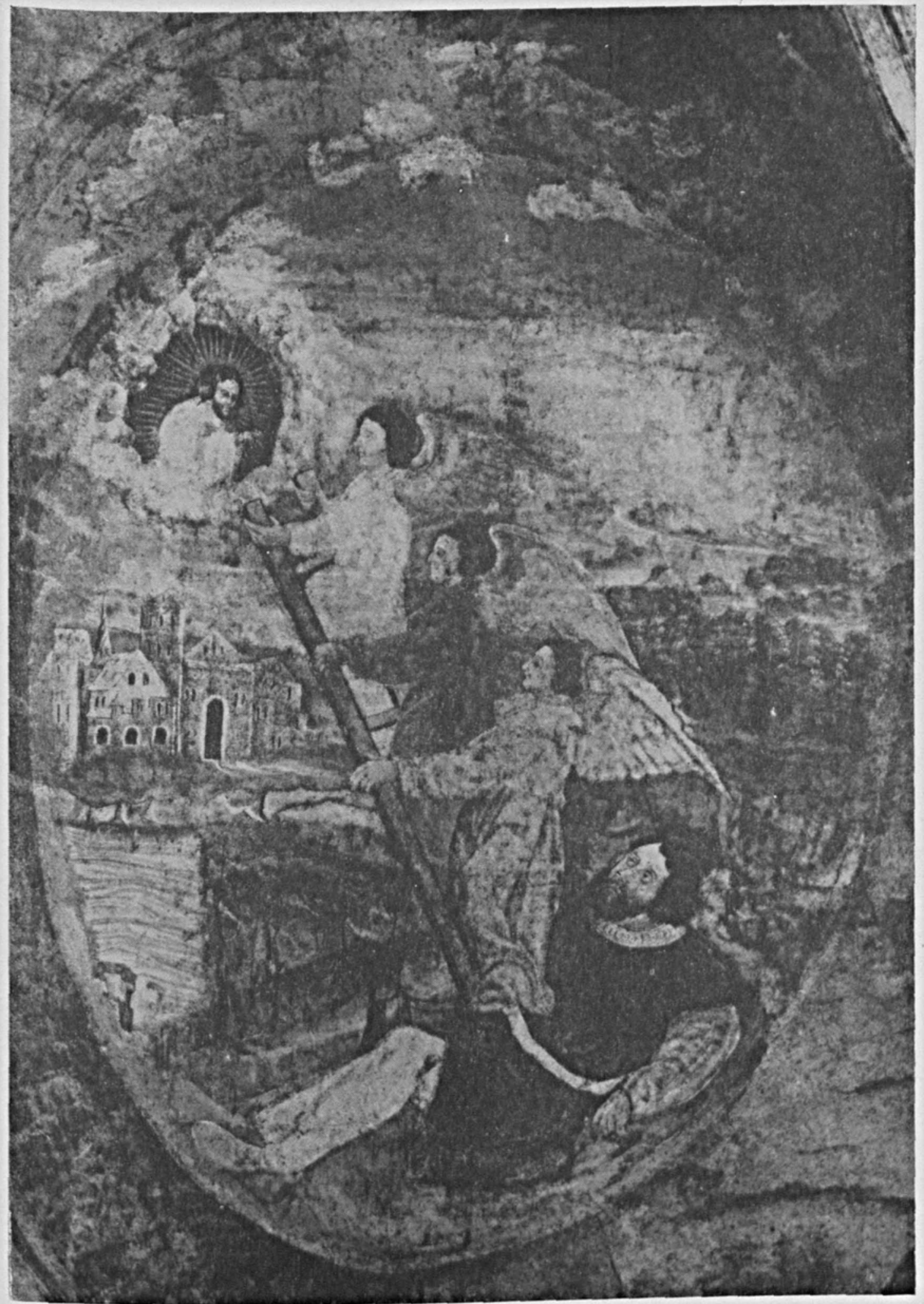

13. Génesis, Cap. xxviri, vers. 13. La escala de Jacuó. 
DOI: http://dx.doi.org/10.22201/iie.18703062e.1964.33.774

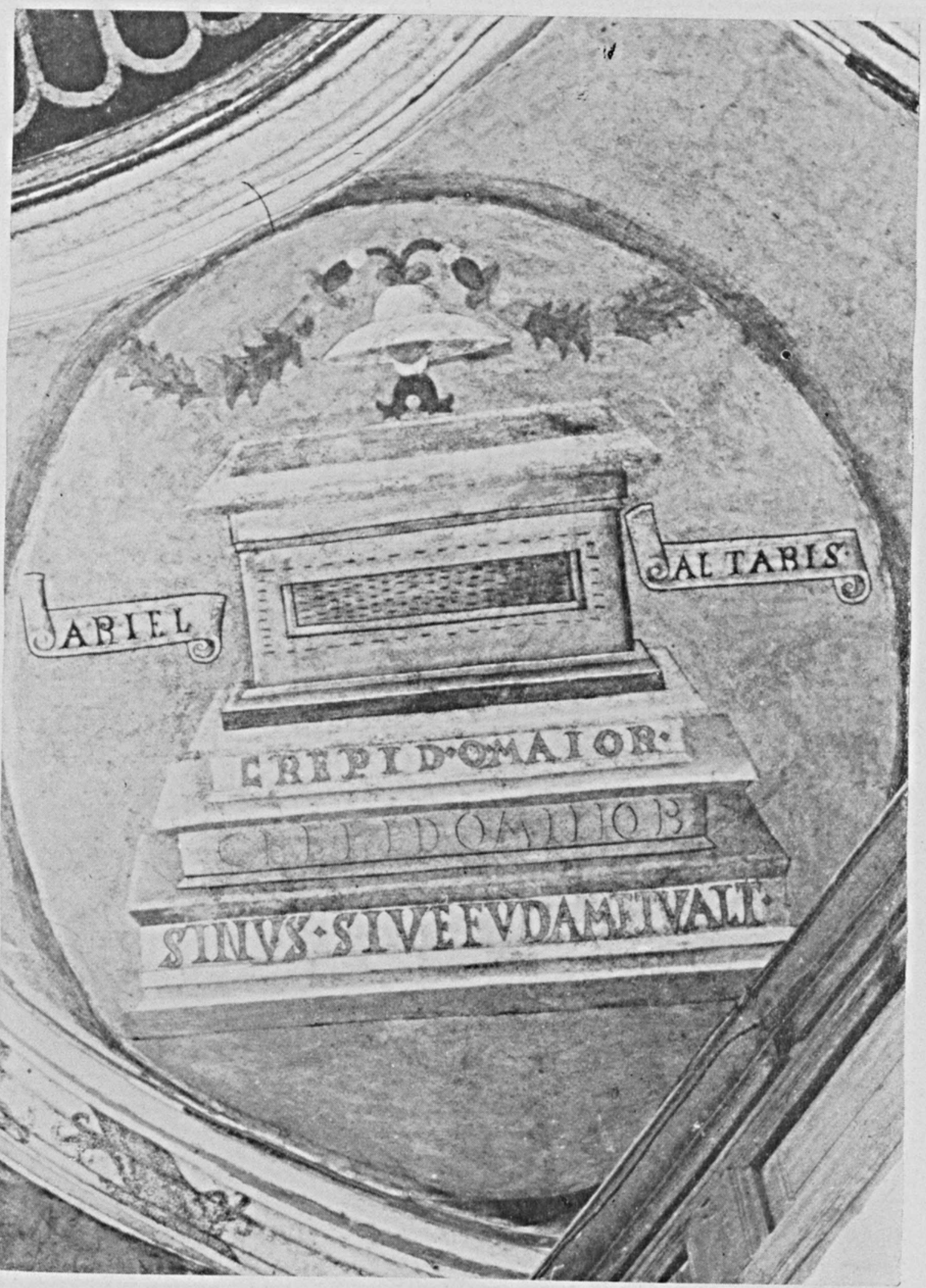

14. Ezequiel, Cap. XlIII, vers. 15. El Altar de Ariel. 


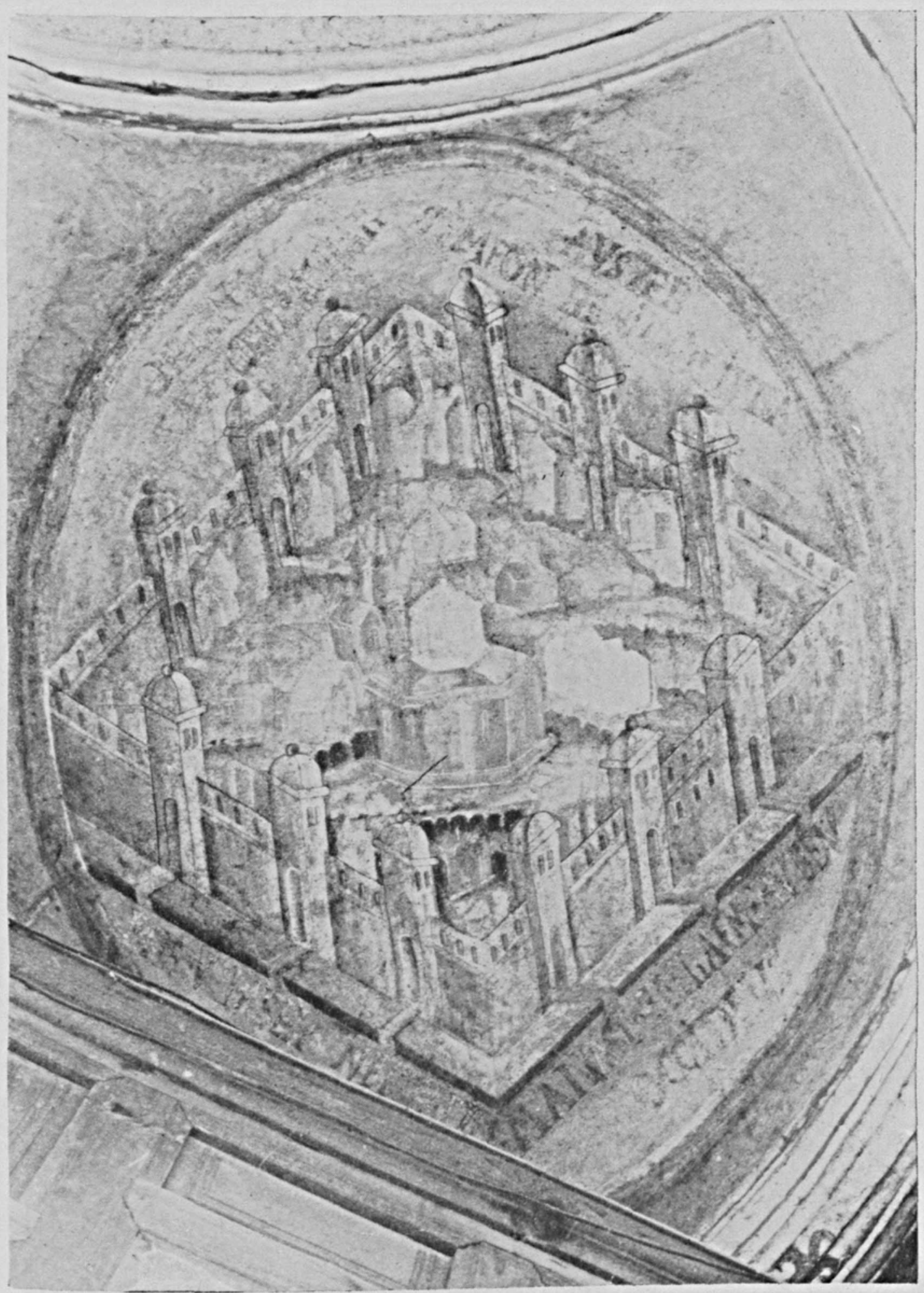

15. Ezequiel, Cap. xLvir. El Templo de Salomón. 


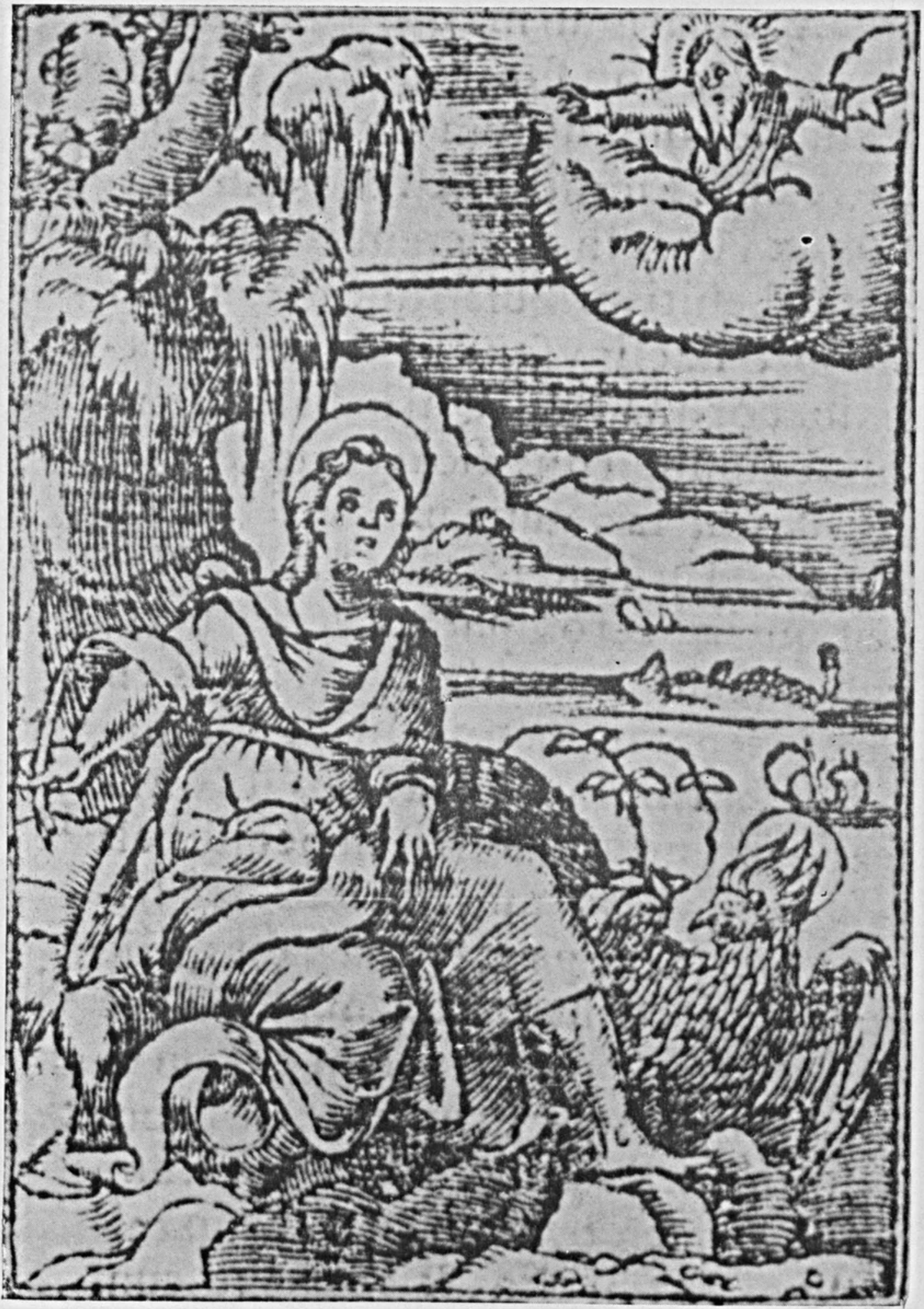

16. Apocalipsis. San Juan escribe el Apocalipsis. 


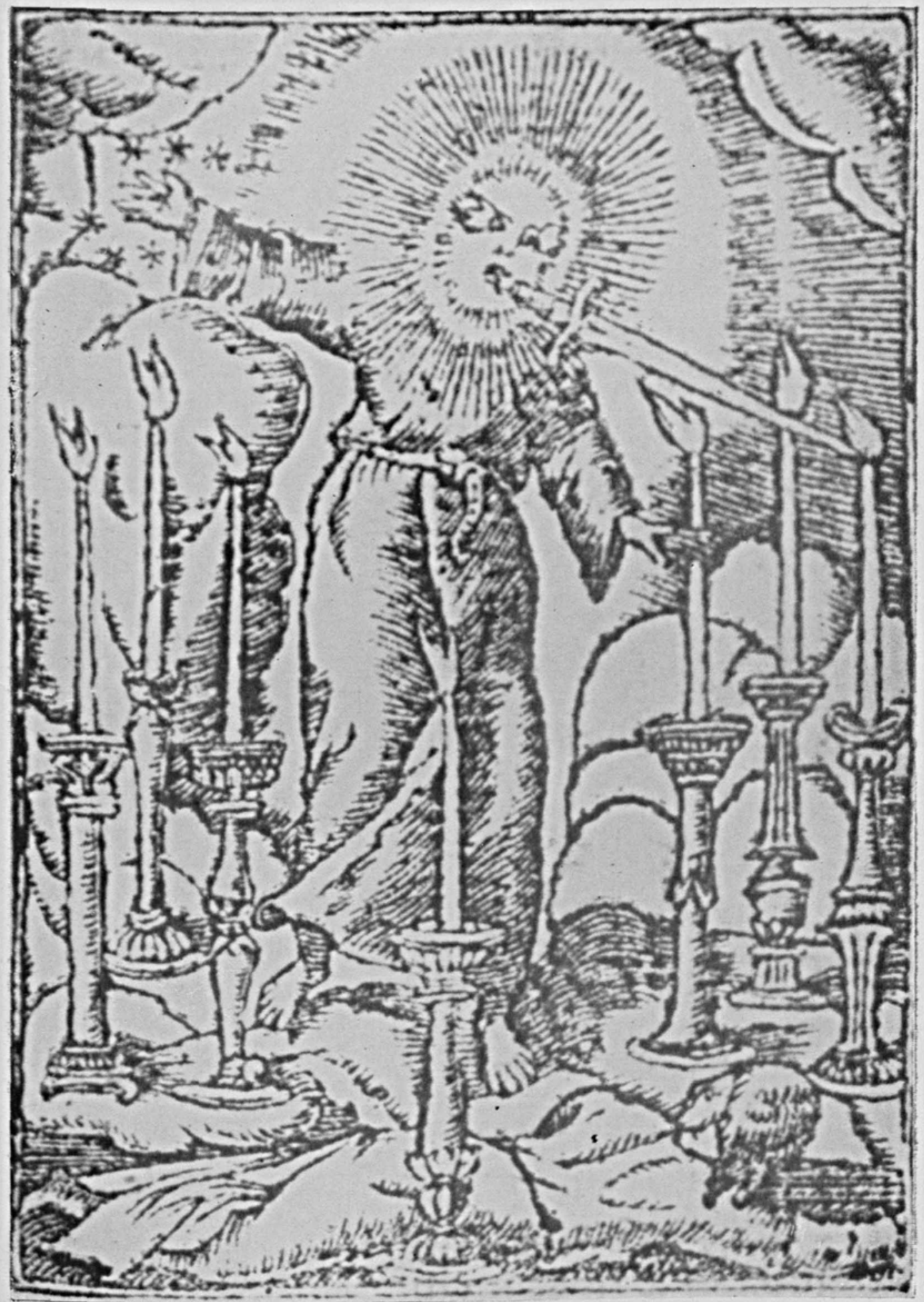

17. Apocalipsis, Cap. I, vers. 17. ... de su boca salia una espada de dos filos... 


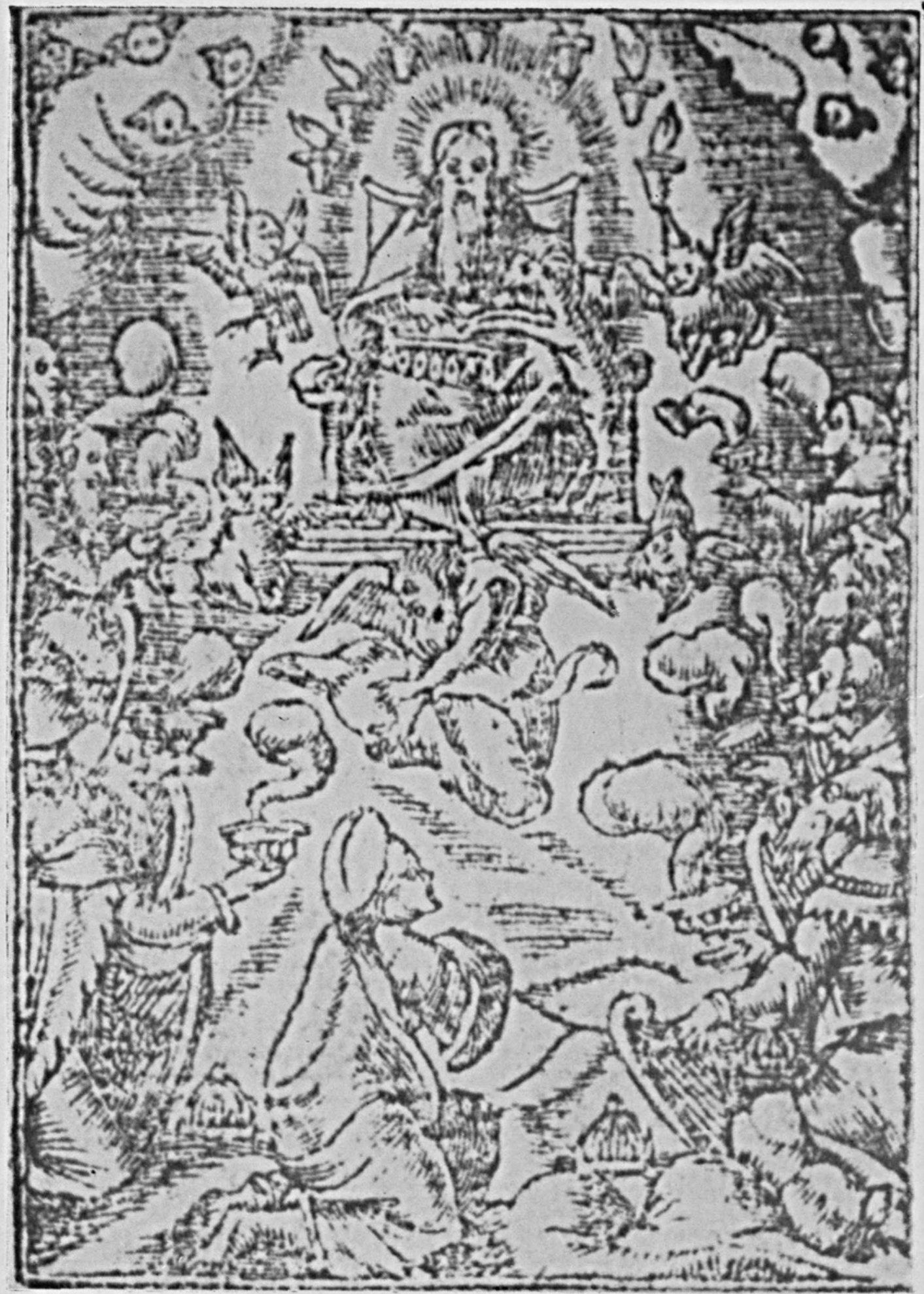

18. Apocalipsis, Cap. Iv, vers. 2. 


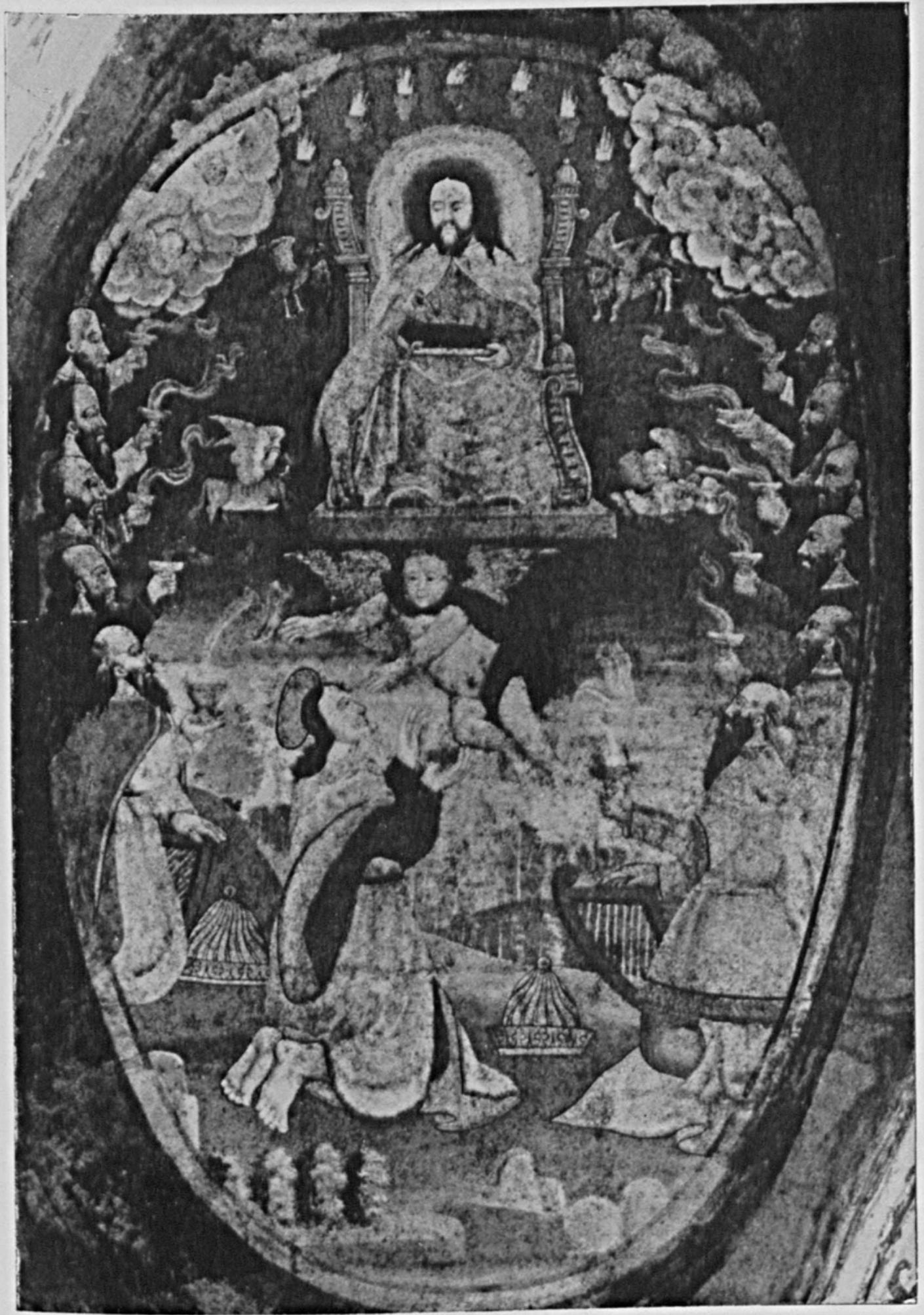

19. ...vi un solio colocado en el cielo y un personaje sentado en el... 


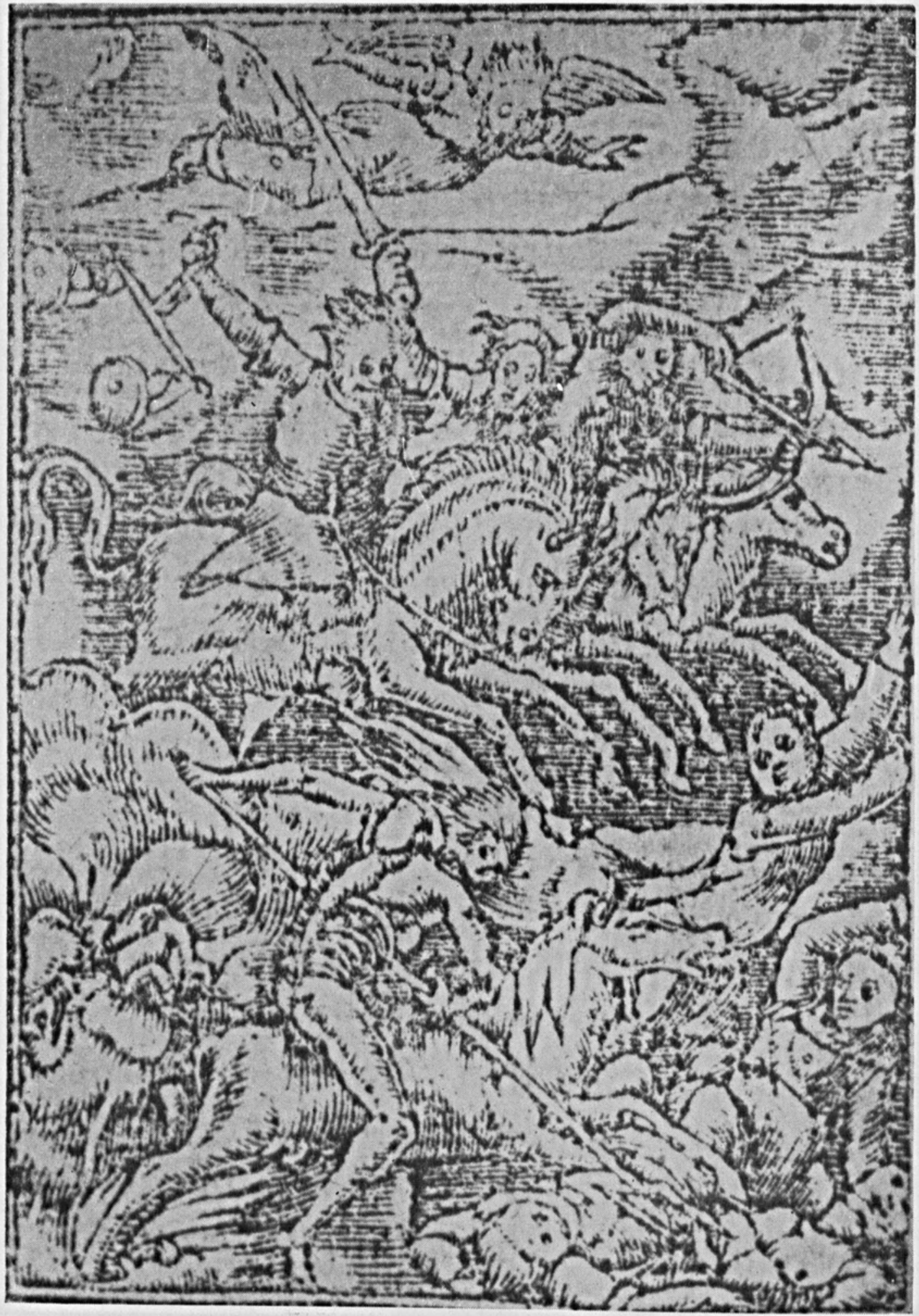

20. Apocalipsis, Cap. vI. 


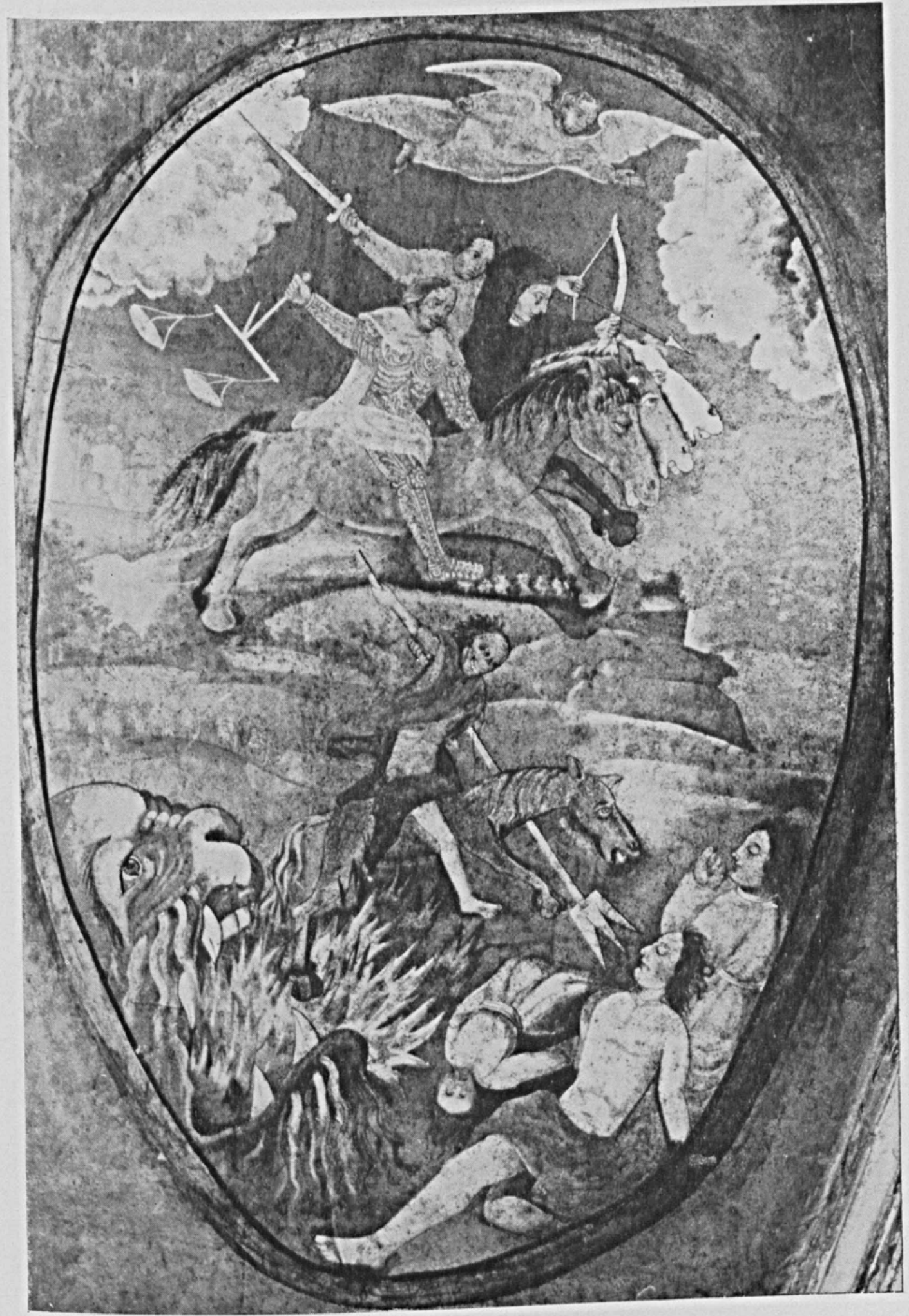

21. Los cuatro jinetes. 


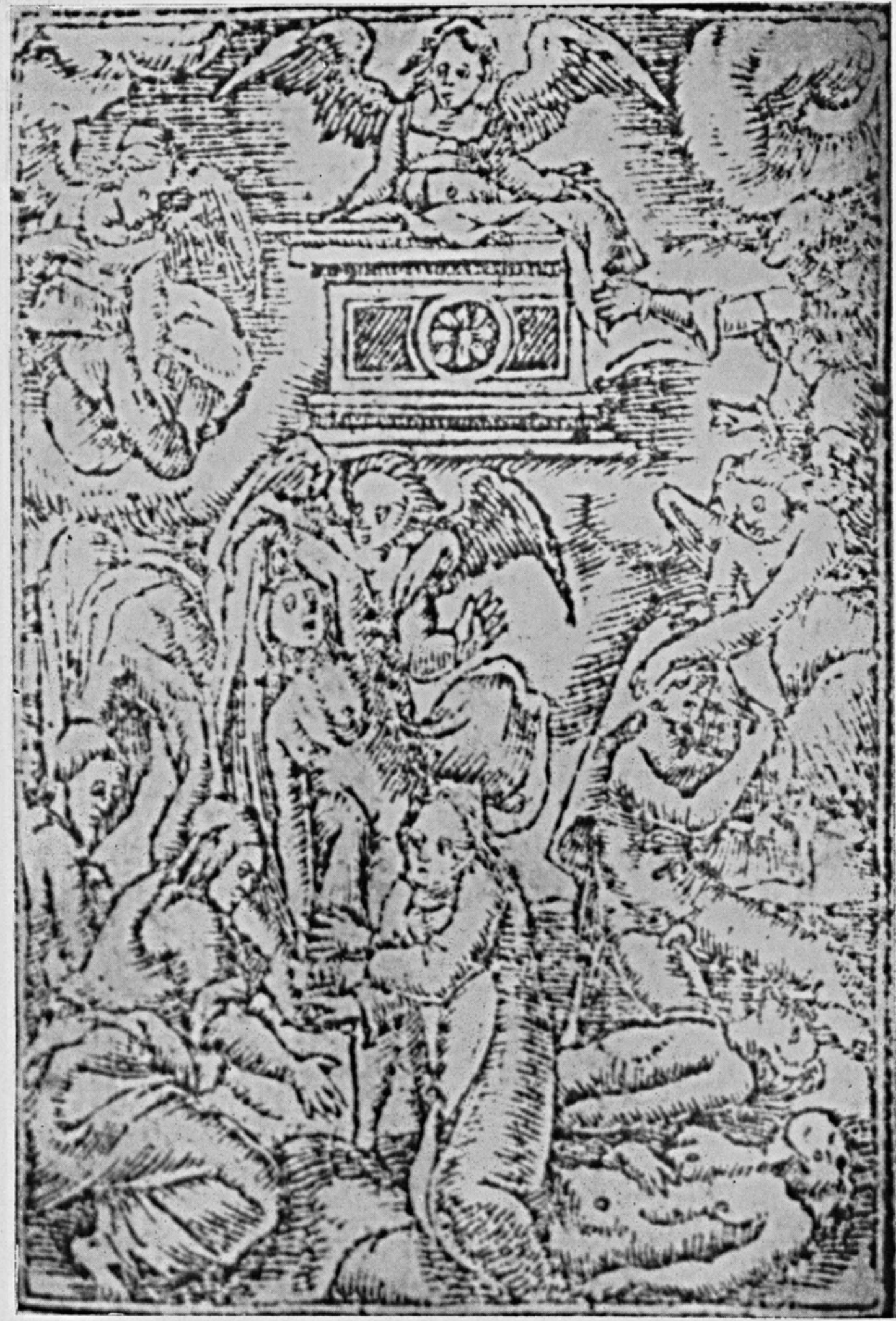

22. Apocalipsis, Cap. vi, vers. 9. 


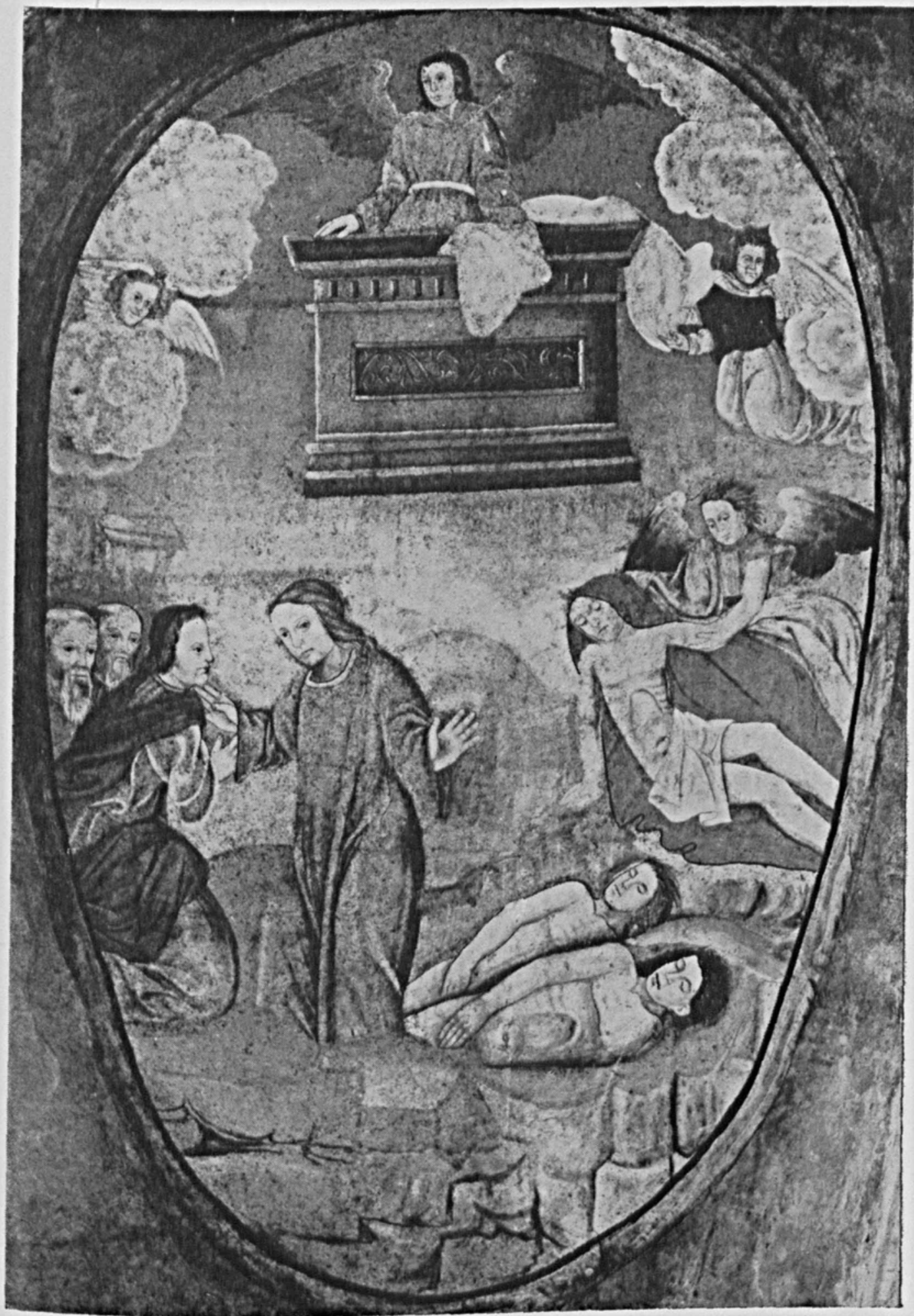

23. La apertura del Quinto Sello. 


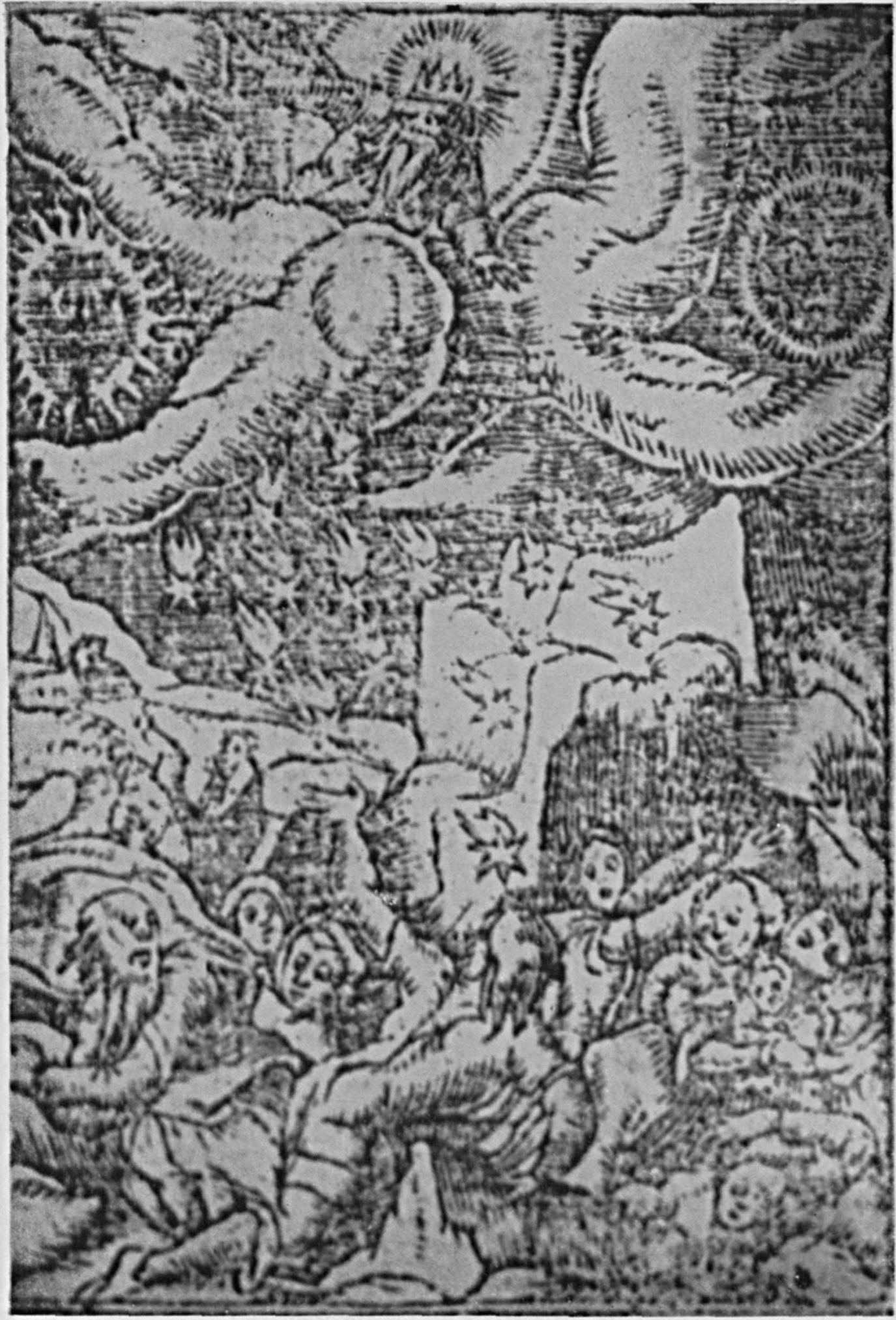

24. Apocalipsis, Cap. vi, vers. 12. 


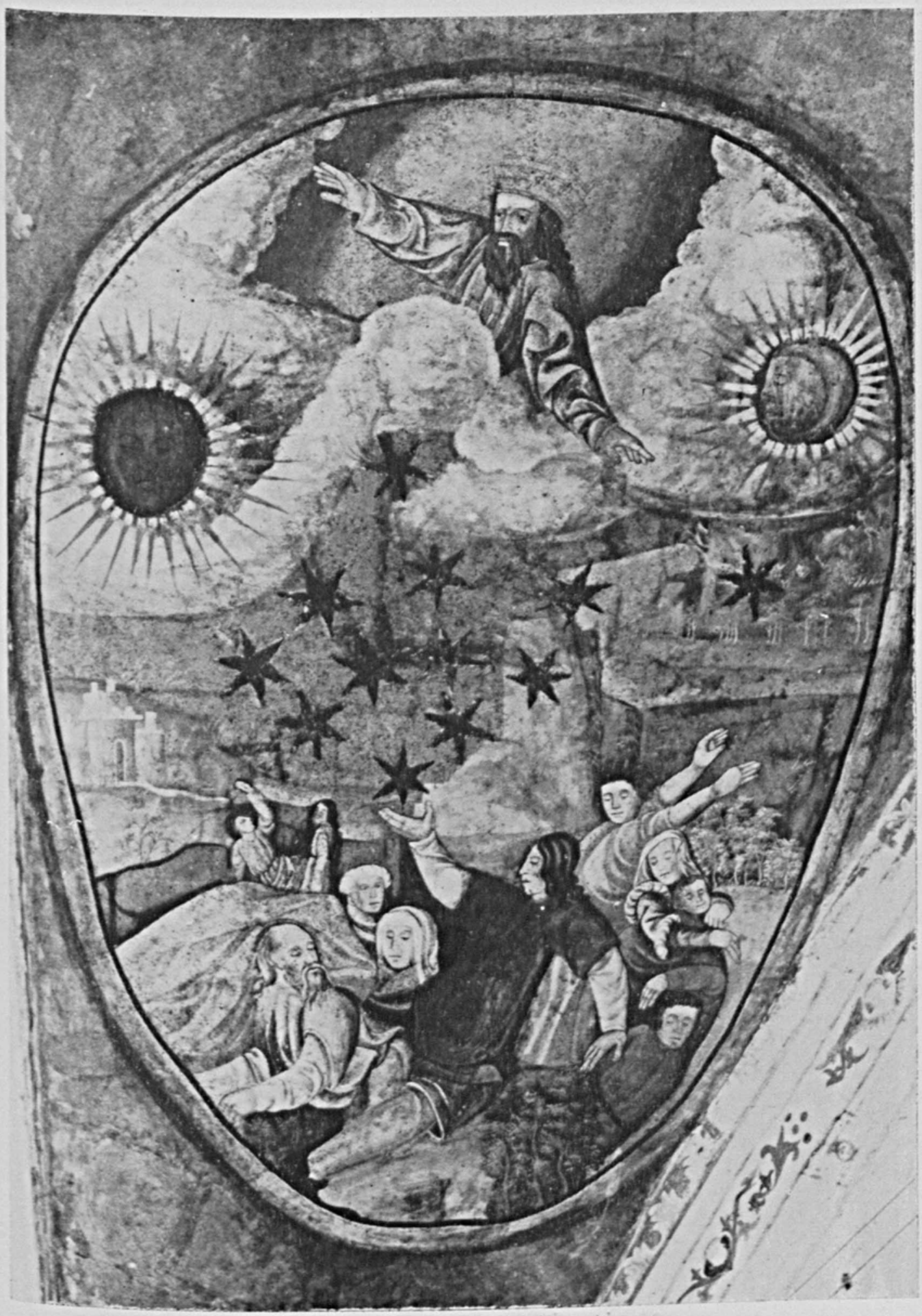

25. La apertura del Sexto Sello. 


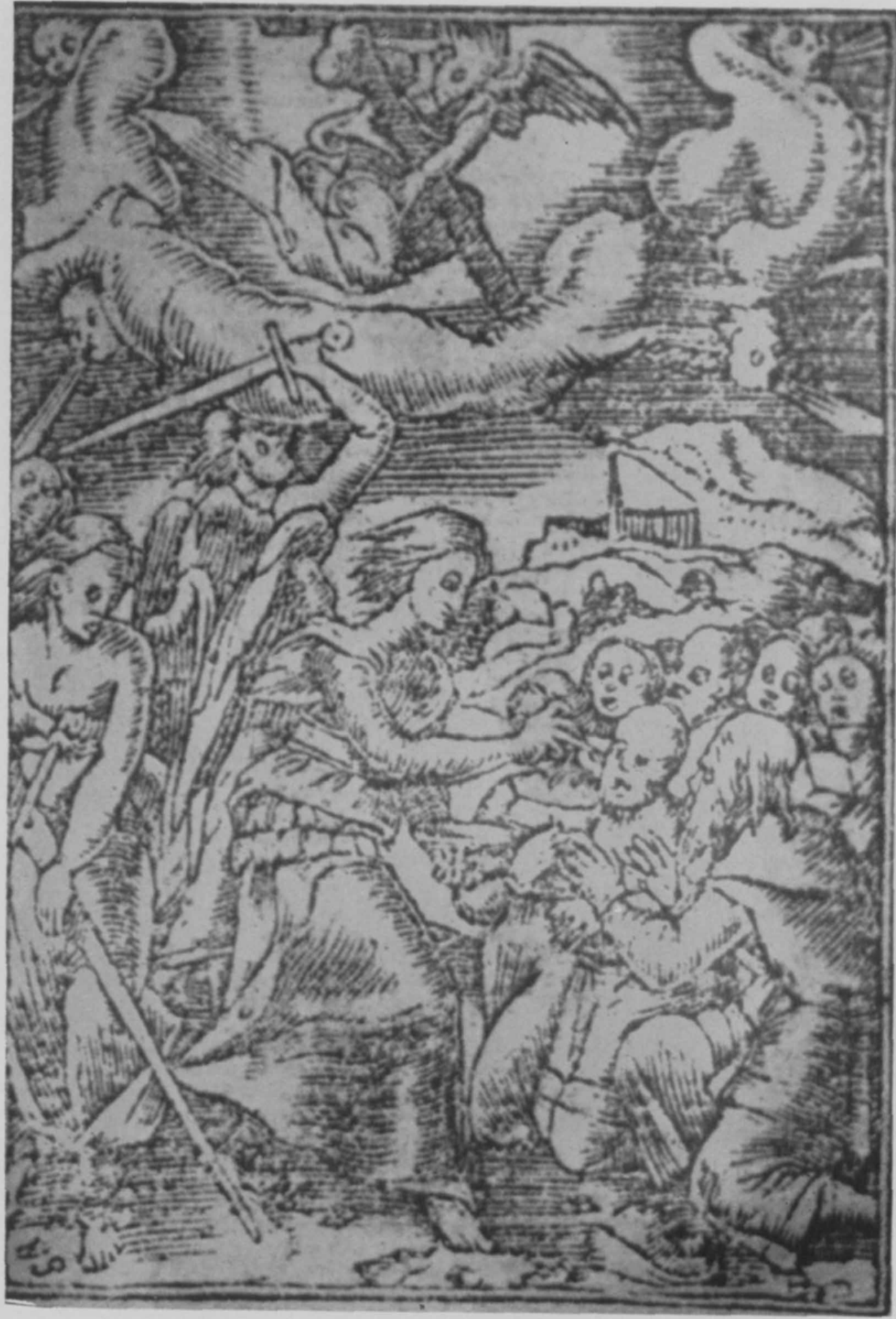

26. Apocalipsis, Cap. vII, vers. 1 a 4 . 


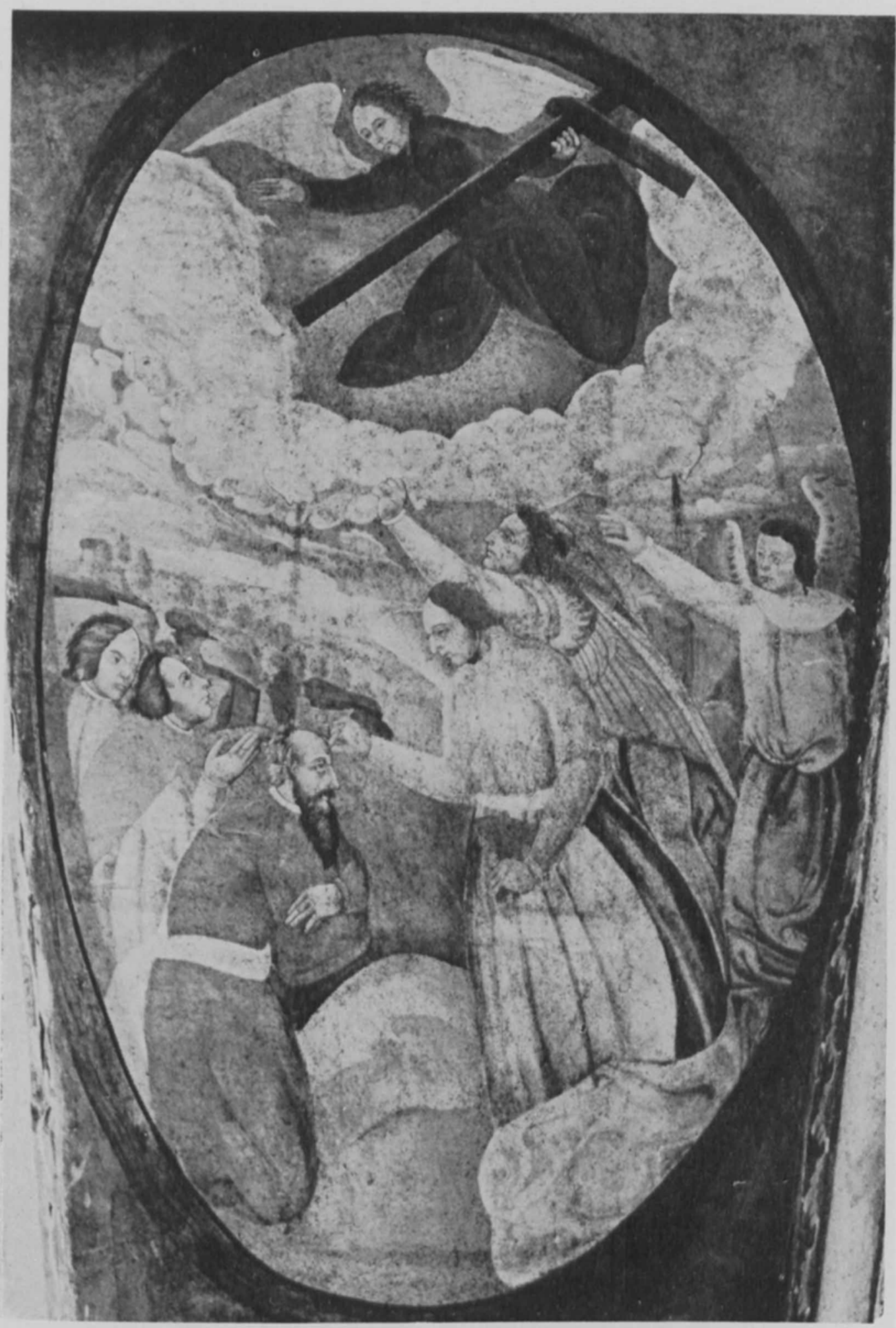

27. Los elegidos de la tribu de Israel. 


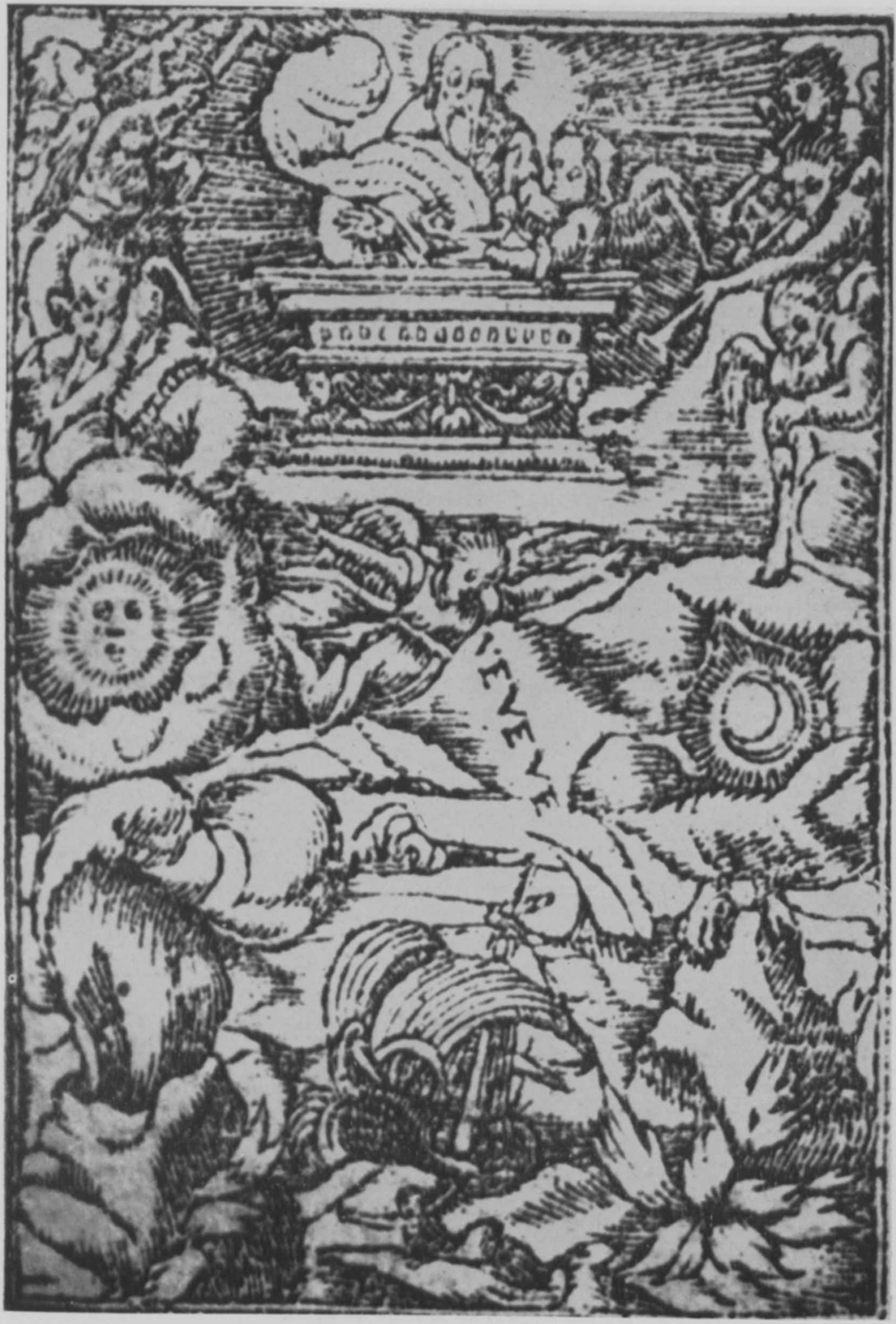

28. Apocalipsis, Cap. vIII. 


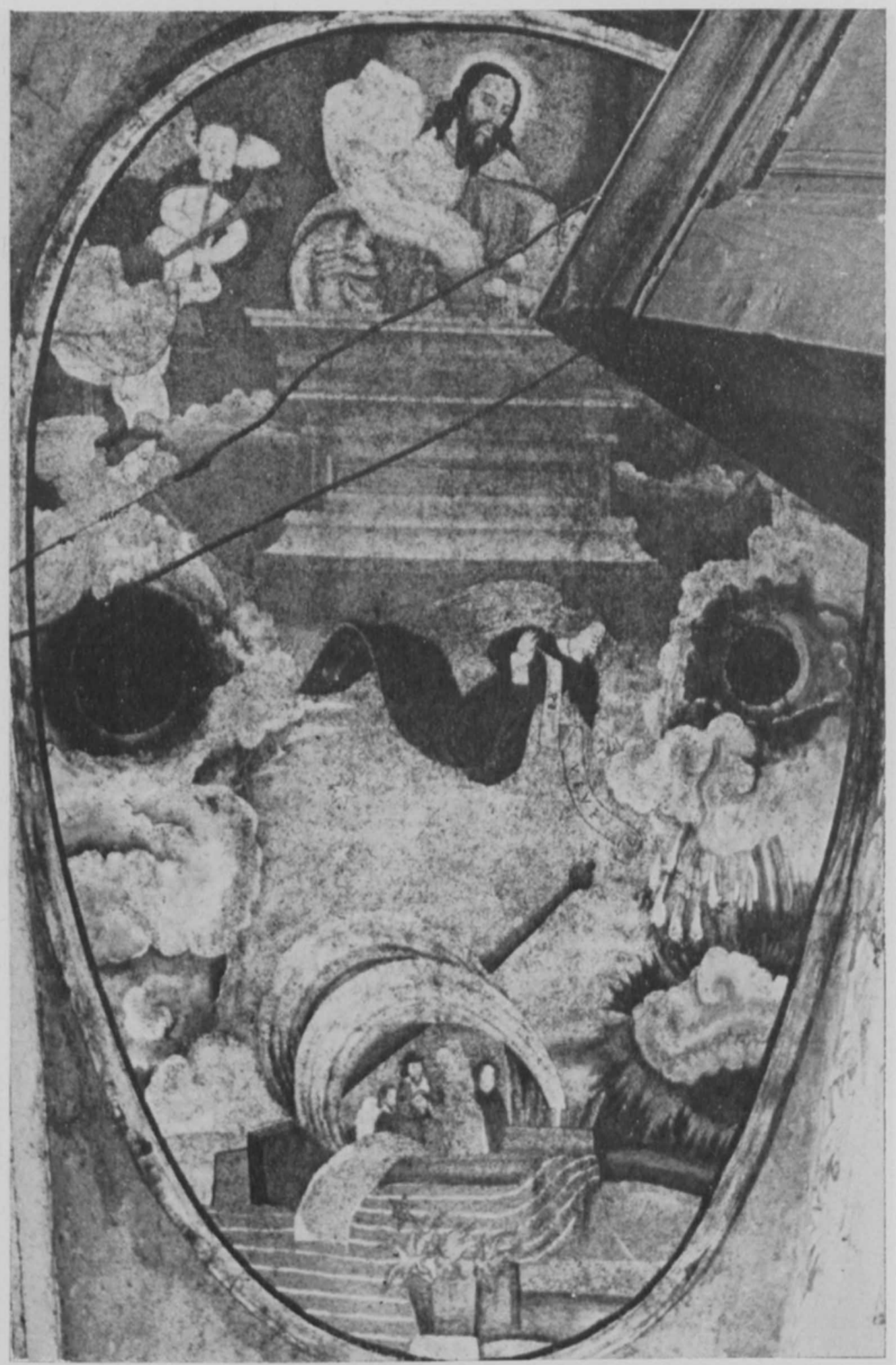

29. La apertura del Séptimo Sello. 


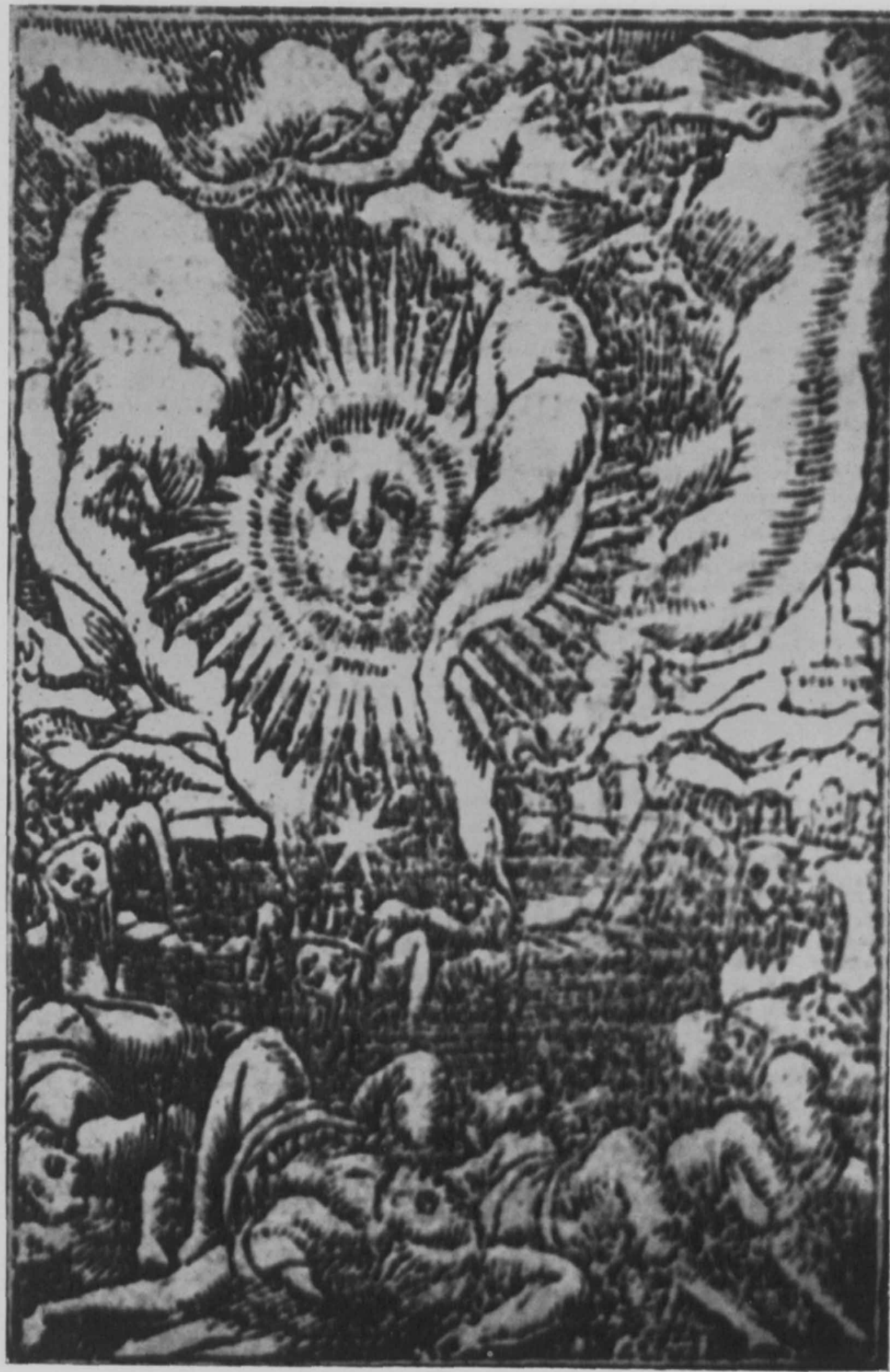

30. Apocalipsis, Cap. Ix, vers. 4 . 


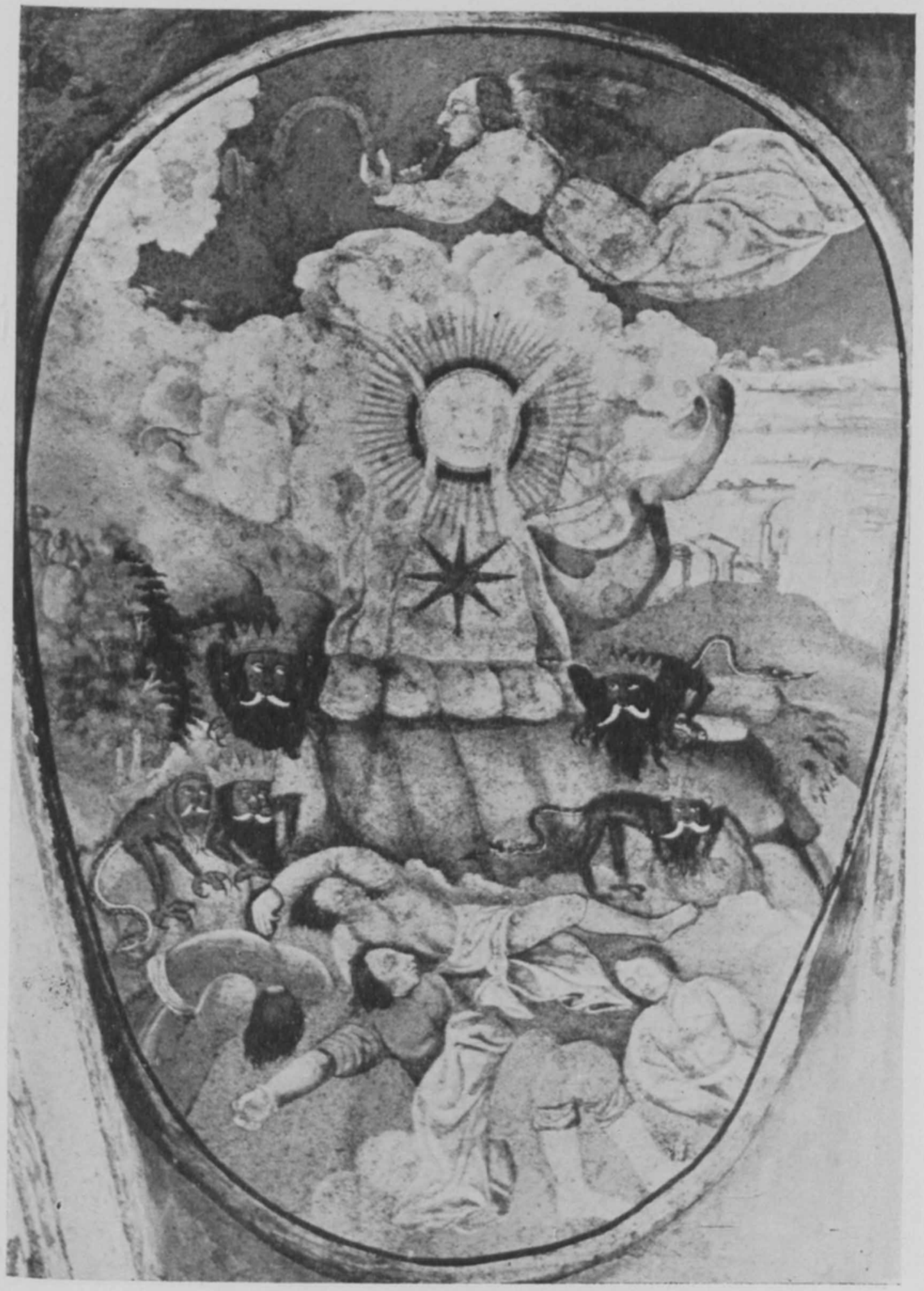

31. El castigo de las langostas. 
DOI: http://dx.doi.org/10.22201/iie.18703062e.1964.33.774

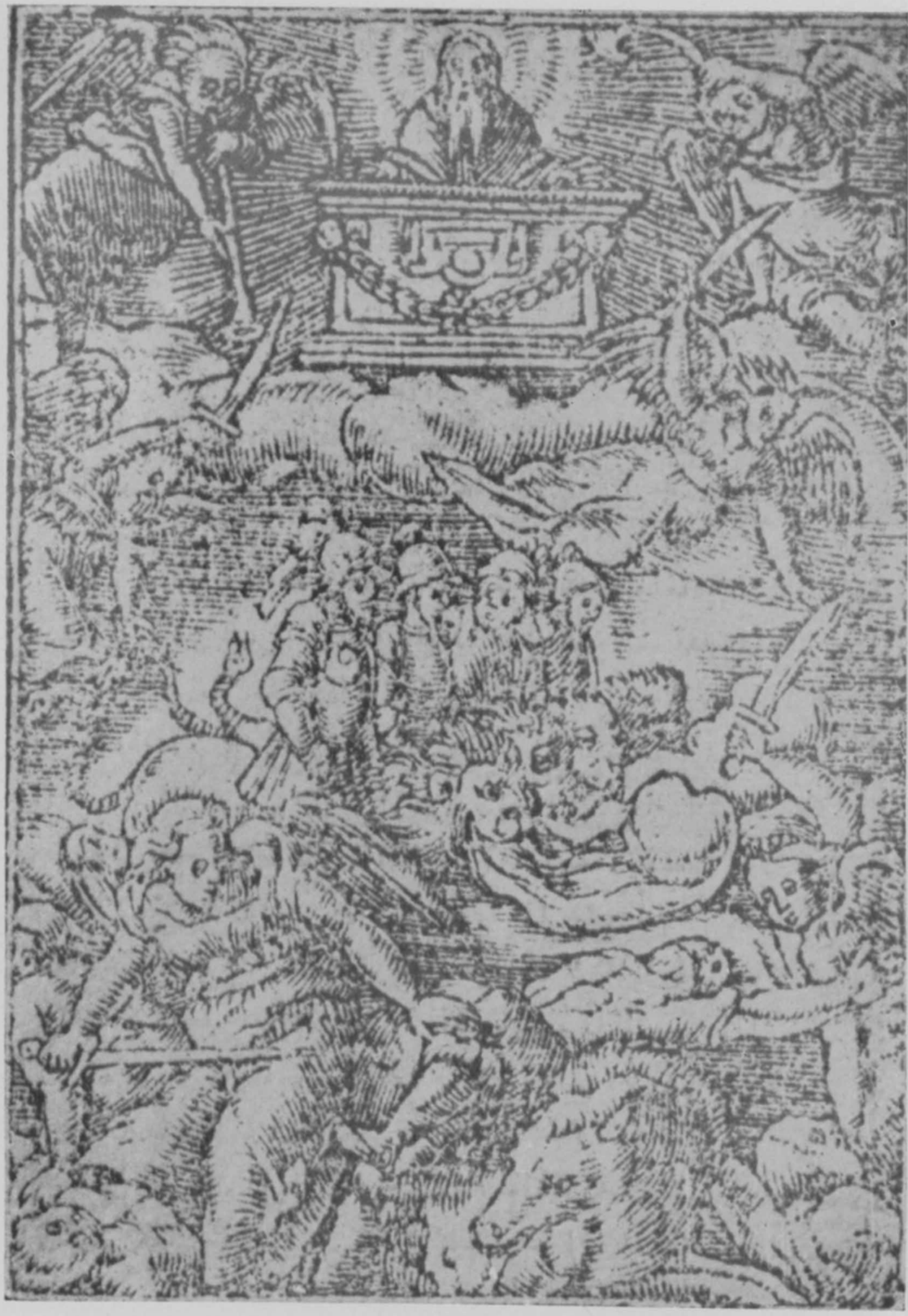

32. Apocalipsis, Cap. Ix, vers. 15. 


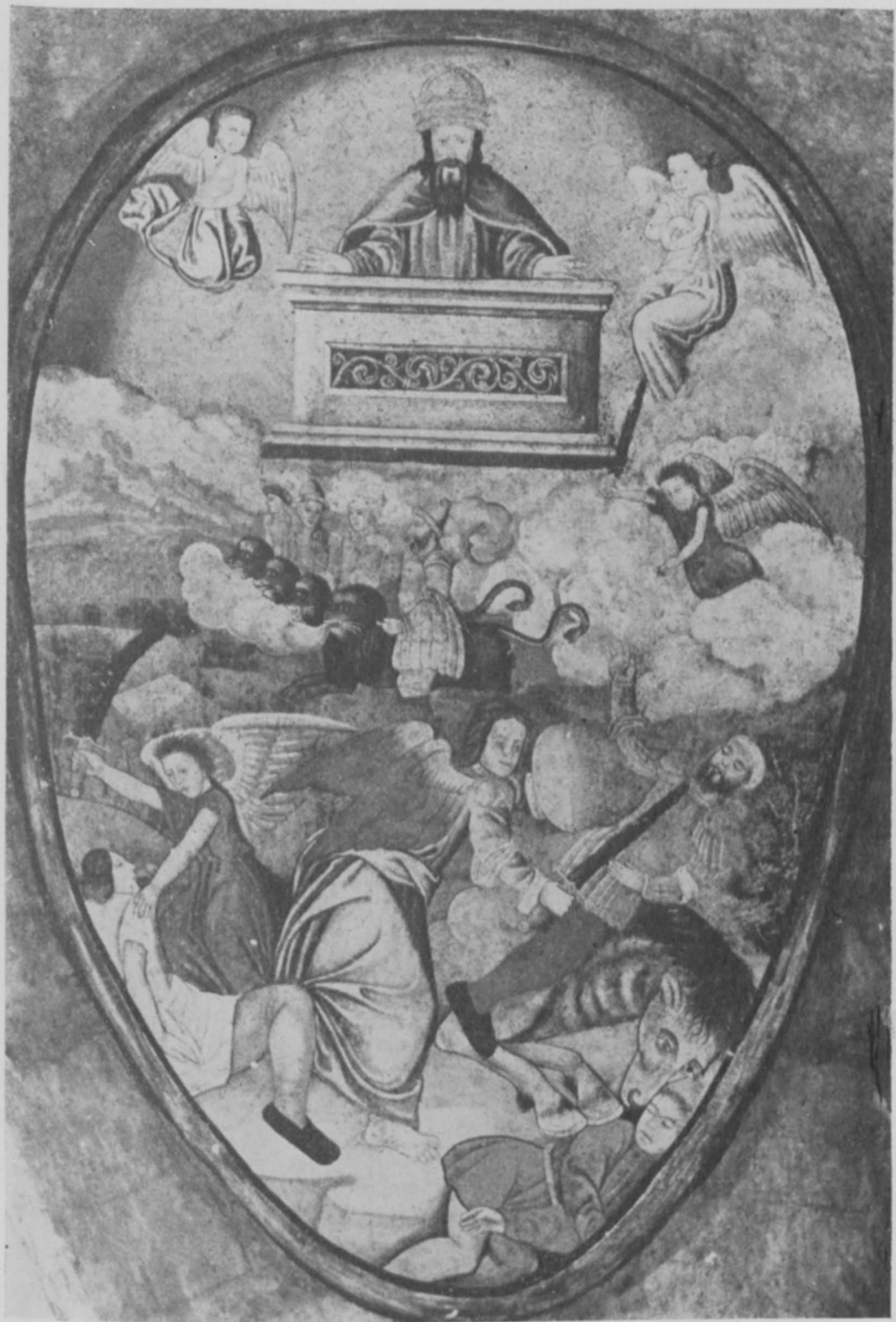

33. Los cuatro ángeles del abismo... 


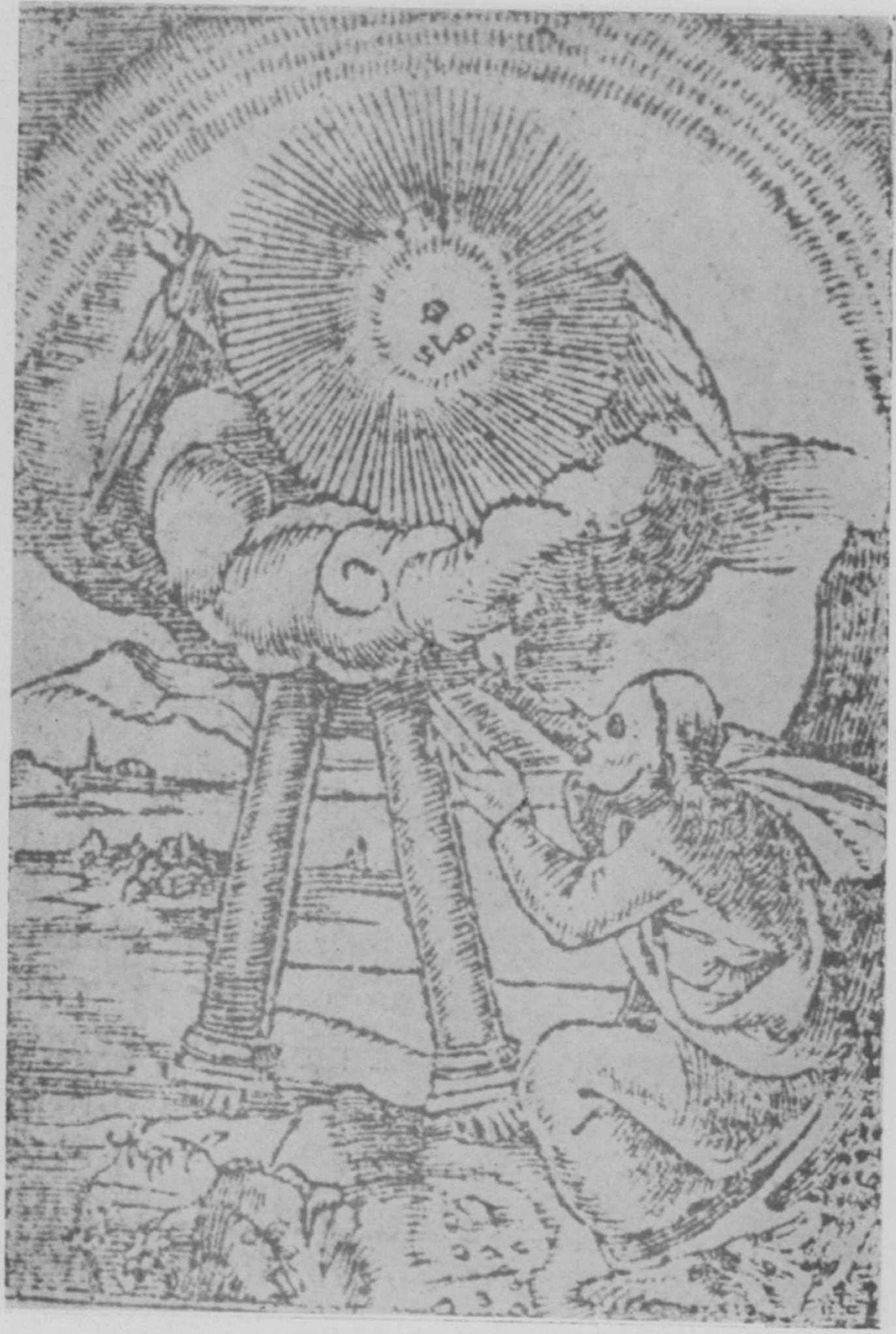

34. Apocalipsis, Cap. $\mathrm{x}$, vers. 10. 


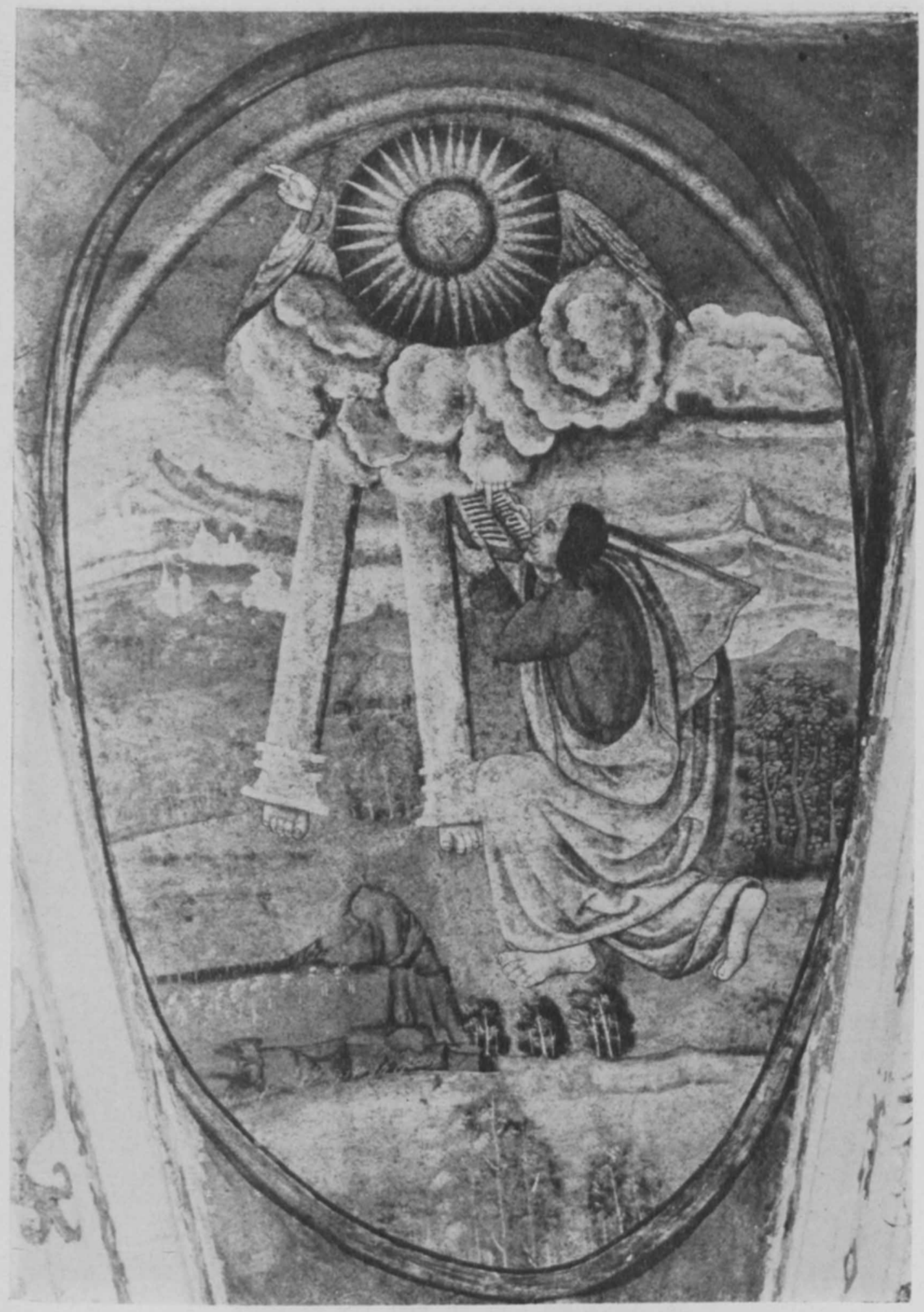

35. Recibi el libro de la mano del ángel y lo devoré... 
DOI: http://dx.doi.org/10.22201/iie.18703062e.1964.33.774

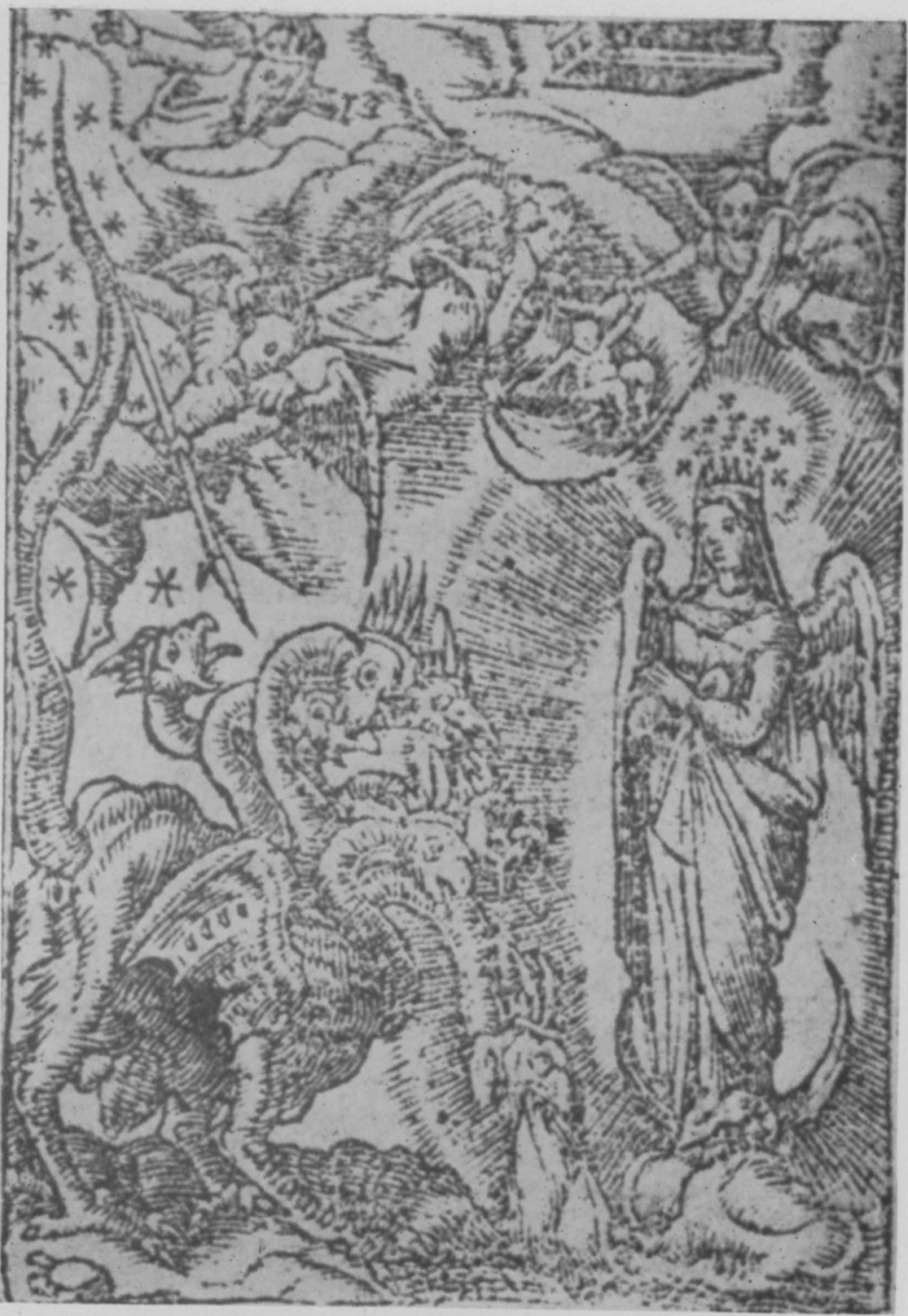

36. Apocalipsis, Cap. XII, vers. 1 y siguientes. 


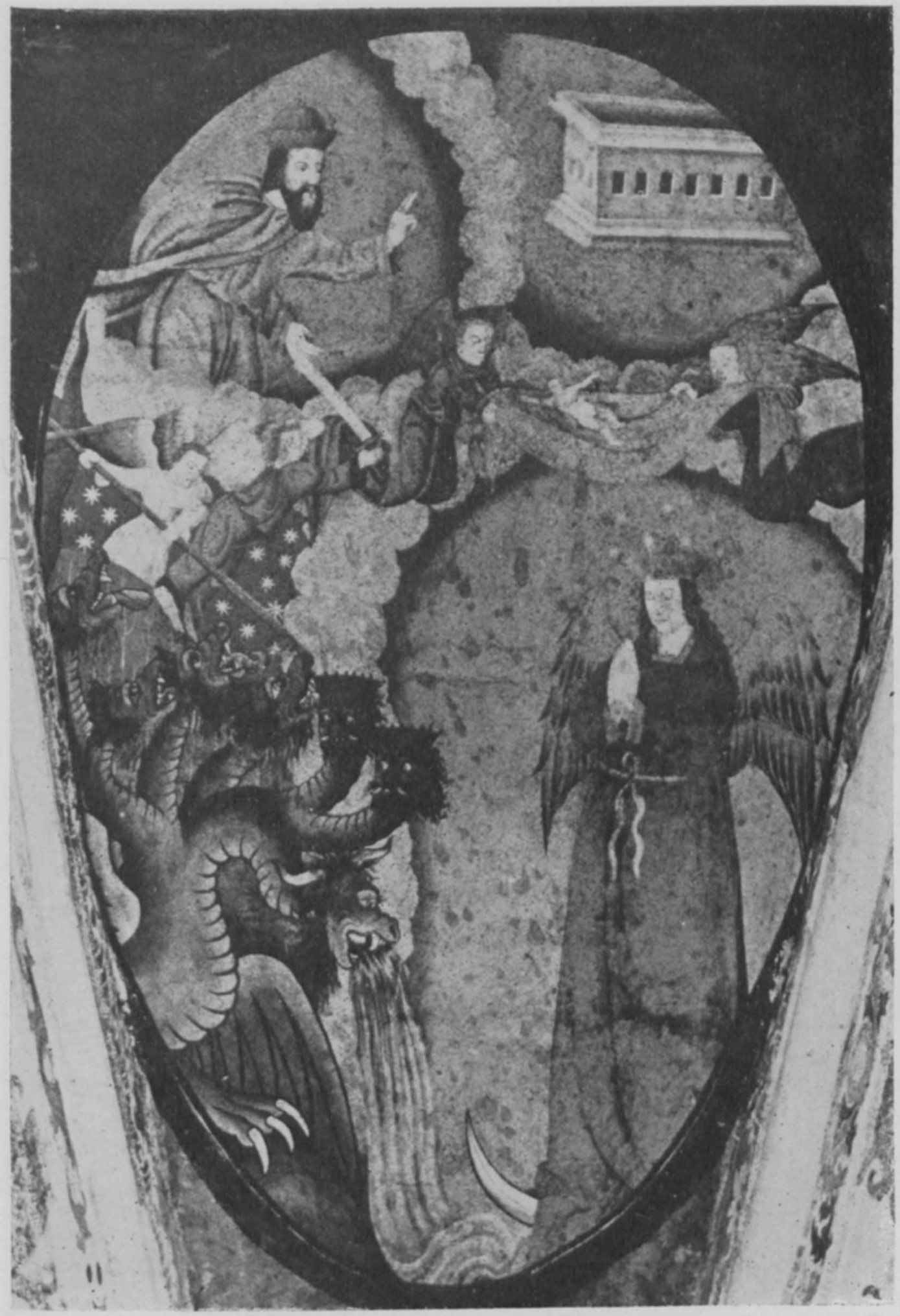

37. La mujer y el dragón. 
DOI: http://dx.doi.org/10.22201/iie.18703062e.1964.33.774

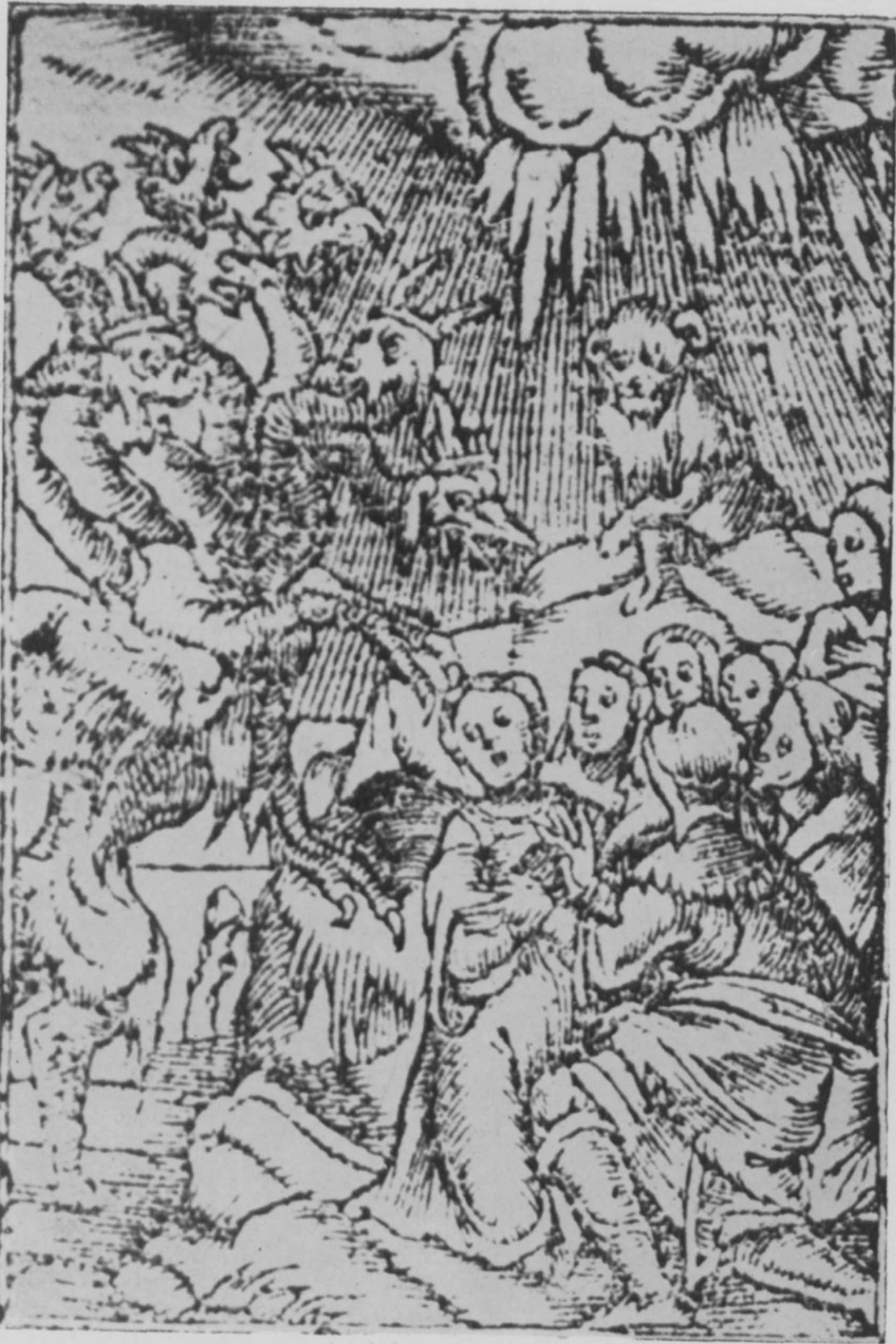

38. Apocalipsis, Cap. XIII, vers. 1 a 16. 


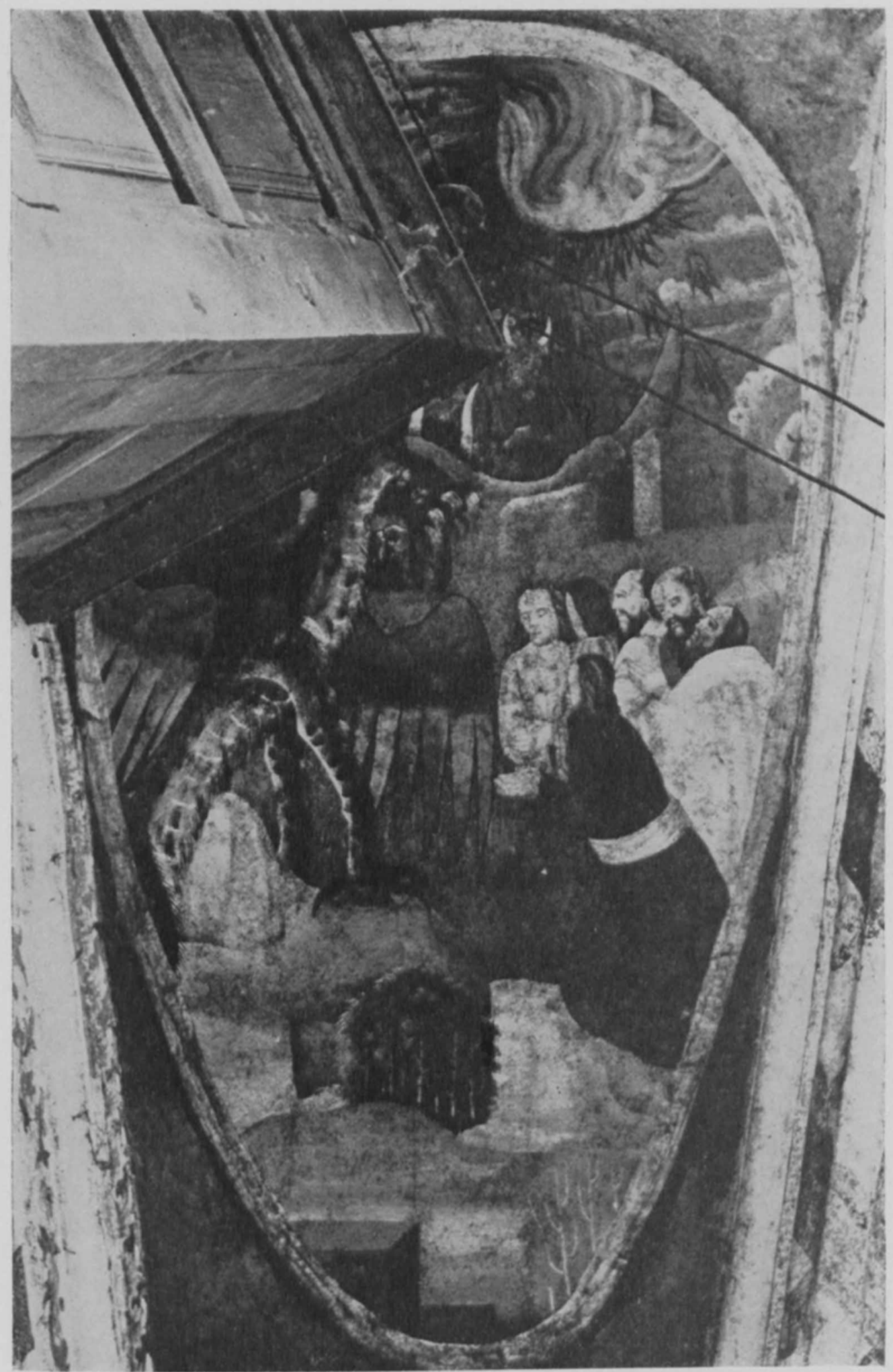

39. Y vi una bestia que subia del mar... 
DOI: http://dx.doi.org/10.22201/iie.18703062e.1964.33.774

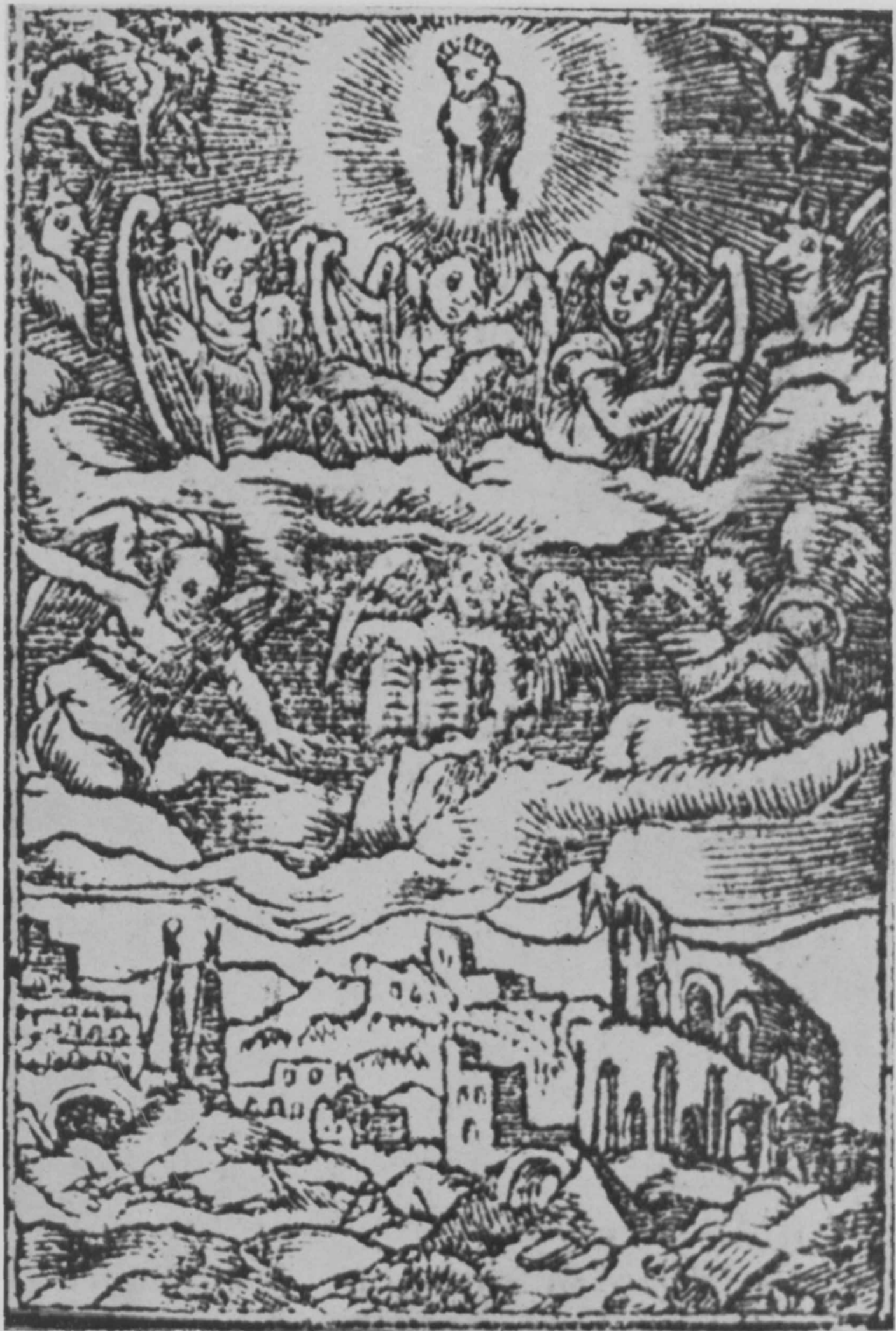

40. Apocalipsis, Cap. XIv. 


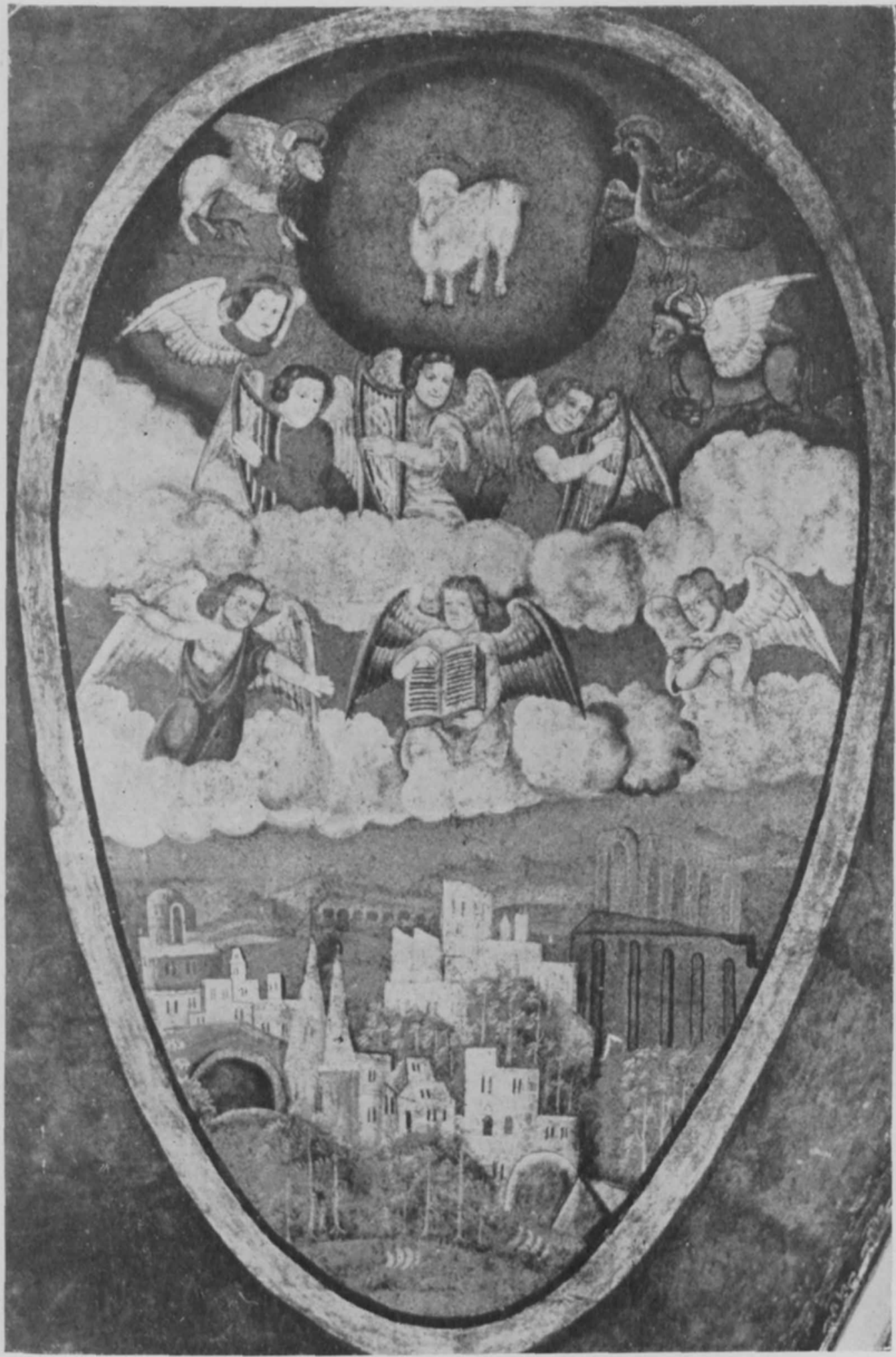

41. El cortejo del Cordero. 


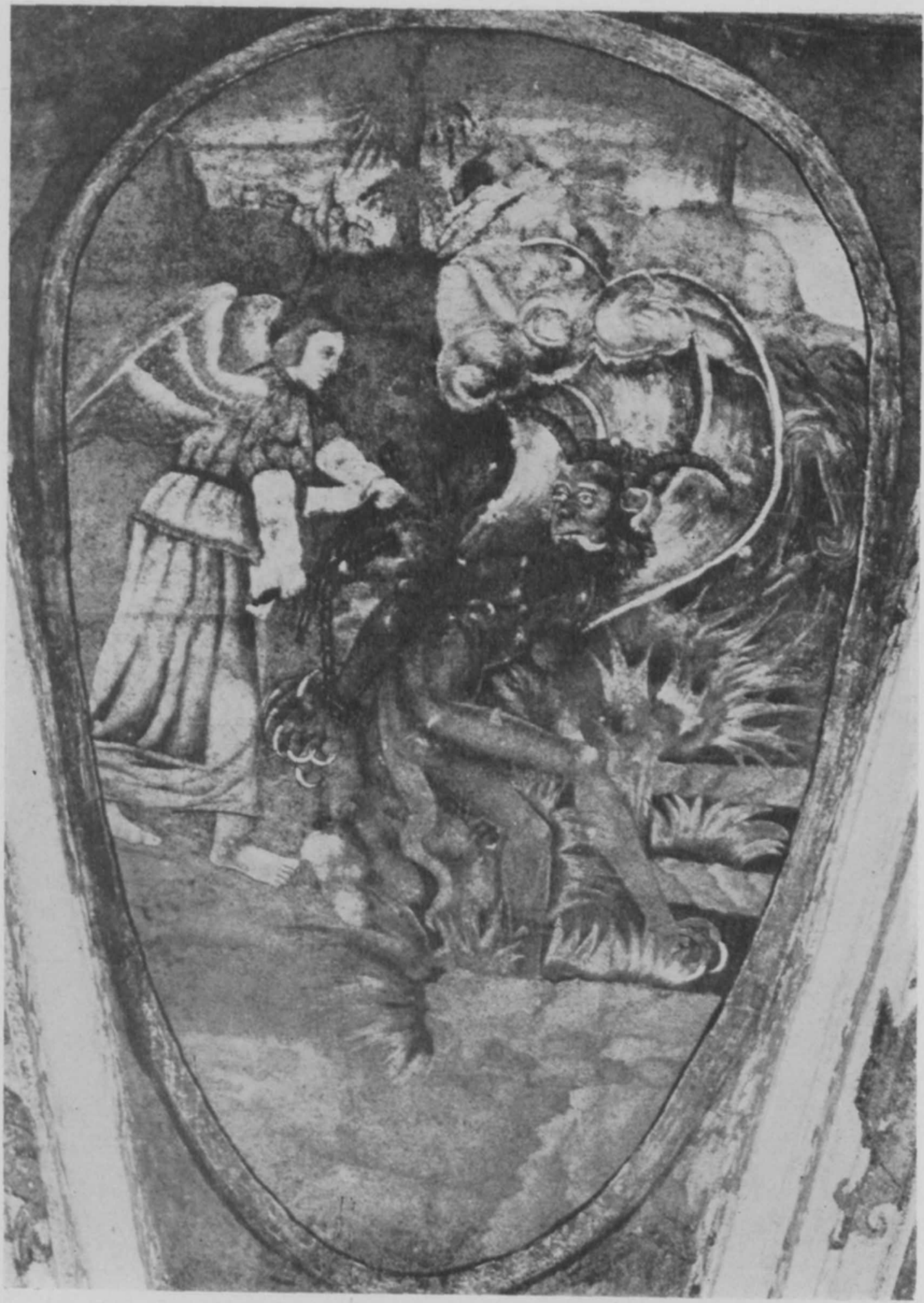

42. Apocalipsis, Cap. xx, vers. 1 a 3 .

Vi un ángel que traia la llave del abismo y una gran cadena... 


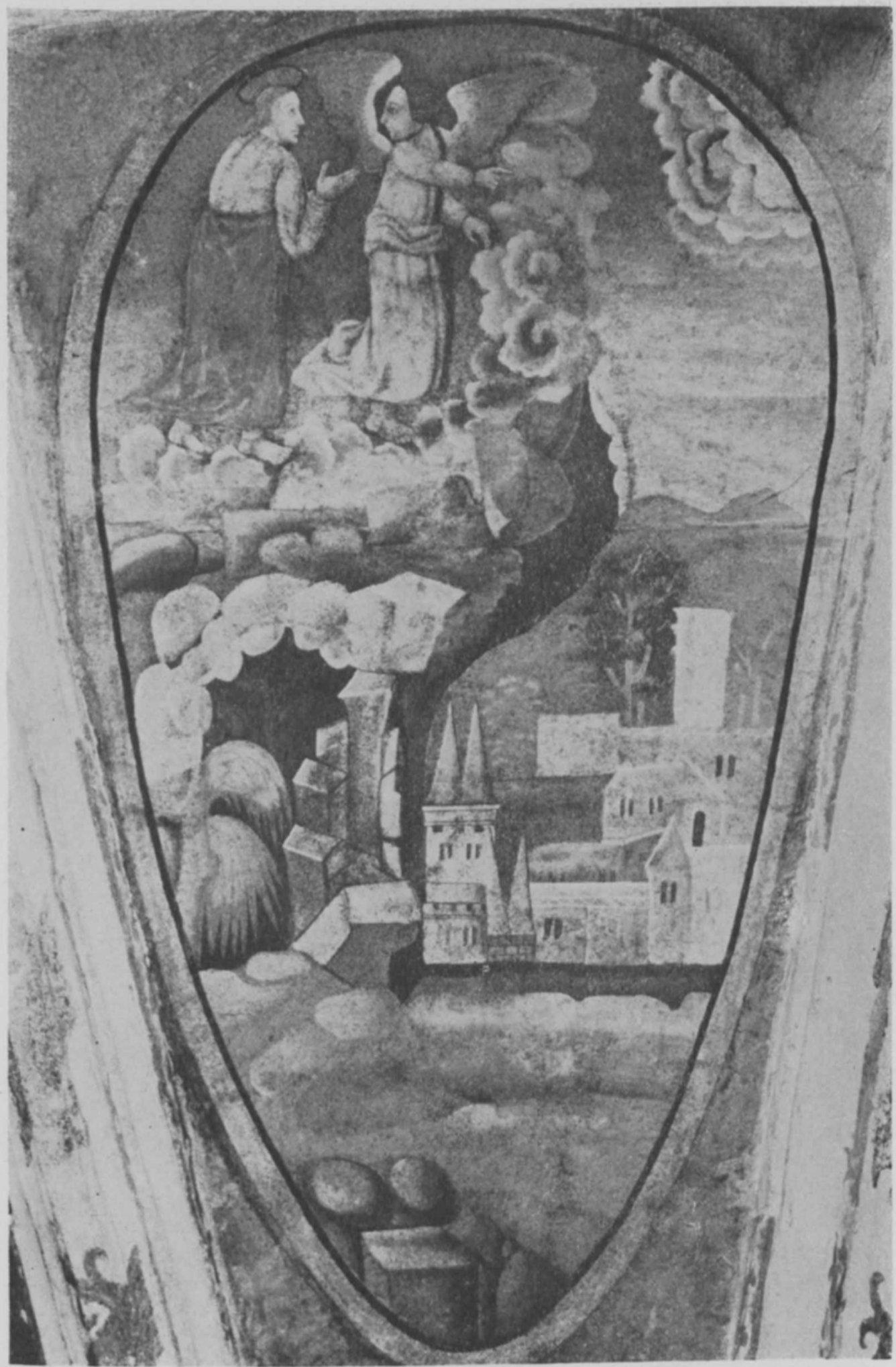

43. Apocalipsis, Cap. xxI, vers. 10.

... me llevó a un monte grande y encumbrado y me mostró la ciudad santa de Jerusalem... 
DOI: http://dx.doi.org/10.22201/iie.18703062e.1964.33.774

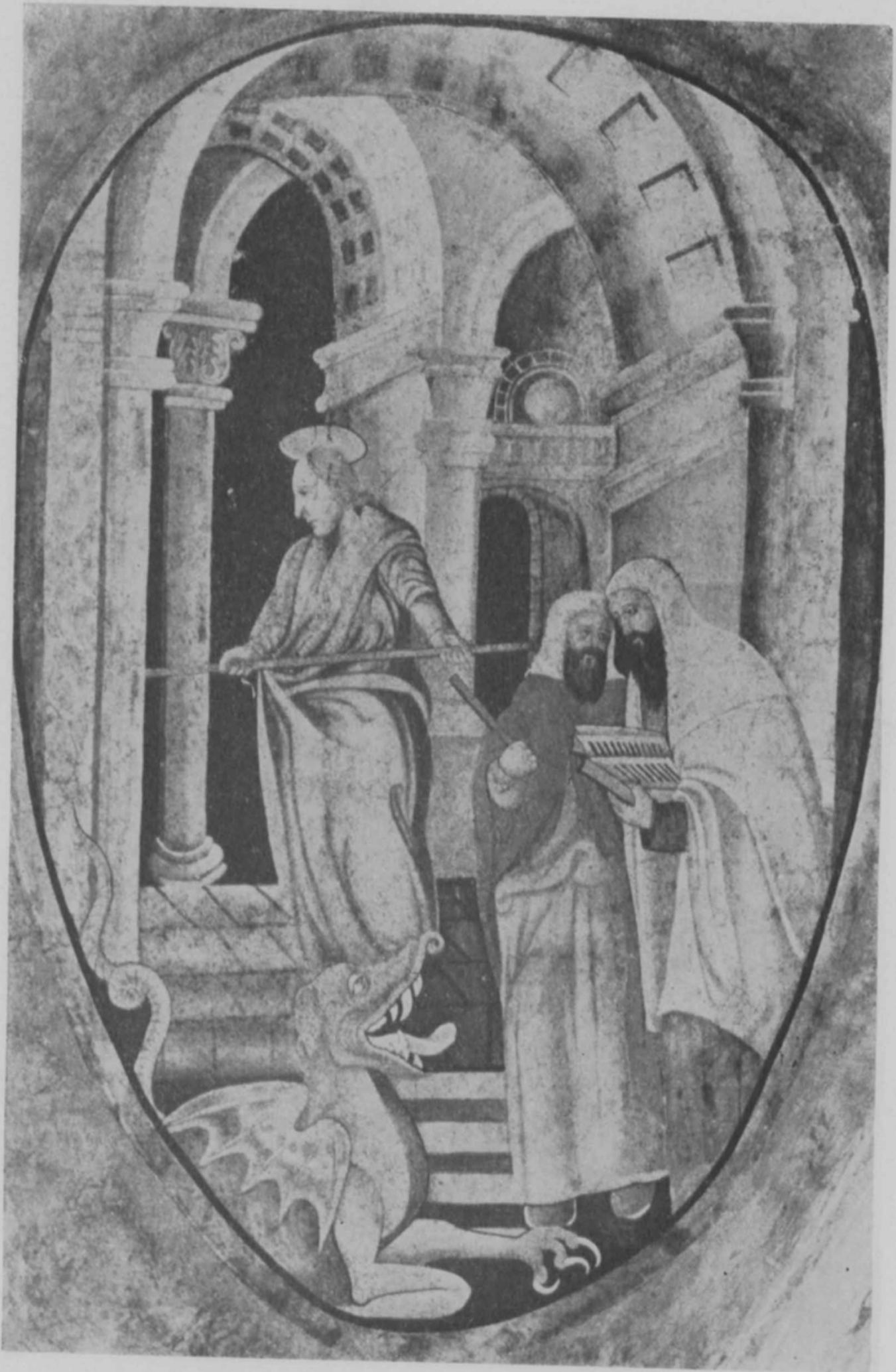

44. Apocalipsis, Cap. xI, vers. 1,3 y 7 . Levántate y mide el templo de Dios. 
dependió su existencia tres veces secular. En el caso de Juan Gerson es probable que éste contó con varias fuentes gráficas para sus pinturas; sin embargo, parece ser que la mayor parte de las mismas, salieron de un ejemplar de la Biblia impreso en Lyon, Francia, en 1558. ${ }^{10}$ De las veintiocho pinturas con que cuenta la bóveda, veintiuna provienen de esta edición. Cinco corresponden al Génesis y las restantes al Libro del Apocalipsis de San Juan. El Altar de Ariel y el Templo de Salomón, figs. 14 y 15, de que hablan las profecías de Ezequiel, vienen de otra fuente que a su vez las ha copiado de los Iconos de Holbein como lo demostró Kubler. De un libro que desconozco, Gerson tomó los símbolos para los medallones de los evangelistas; el arcaísmo de sus formas nos hace pensar en grabados inspirados aún en el arte medieval, sobre todo los correspondientes al León de San Marcos, fig. 5 y el Hombre Alado, de San Mateo. Un pasaje del Apocalipsis, el que corresponde al capítulo XI, versículos 1,3 y 7 , relacionado con la medición del templo, ha salido cle otro grabado, de origen italiano tal vez, así lo demuestran tanto los personajes, como la arquitectura de corte renacentista que tienen al fondo, fig. 44. Esta escena es enteramente distinta a la que aparece en la lámina de la Biblia de 1558.

Antes de continuar adelante es necesario hacer una aclaración. He asentado líneas atrís, que tal vez nuestro artista utilizó otros libros aparte de la mencionada Biblia de 1558, de la cual provienen la mayoría de sus pinturas. Sin embargo, esto hay que tomarlo con absoluta reserva, pues acaso el pintor tuvo a mano una edición de la Biblia distinta it la que hemos iclentificado y la cual, por consiguiente, contenía todas las estampas que copiú. Esto no es improbable, ni resulta una novedad el que varias casas editoras utilizaran idénticas xilografias, puesto

19 En la Biblioteca Nacional de México, en el Fondo de Biblias provenientes de los viejos consentos, localicé un ejemplar de esta edición; por desgracia está mutilada; fáltale, sobre todo, la portada en la que se dan las noticias de su editor. Gracias a las diligencias y a la fineza de mi distinguido amigo el profesor Pál Kelemen, pucle identificar la eclición del ejemplar de nucstra máxima Biblioteca. El que el señor Kelemen localizó, pertence a la Biblioteca de San Marcos, del General Theological Seminay, de New York: Biblia Sacra, Ex postremis Doctorum omnitum rigilijis, ad Hebraicam verilatem, \& probatissimorn exemplariu fidem. Cum Hebrai. corum nominum interpretatione. Lugduni, Apud Jacobum de Millis, M.D.LVIII. El colofón reza así: Lugduni, Excudebat loames Pullon, alias de Trin. Me causa gran satísfacción el dar las gracias aquí, al señor profesor Pál Kelemen, por su desinteresida y valiosa ayuda. Asimismo, quiero dejar constancia de mi agradecimiento por la ayuda prestada para la identificción de la Biblia citada, a los señores profesores Jorge Alberto Manrique, de París, Francia; Joseph A. Baird Jr, de Fairfax, Calif. L'S.A. y Salvador Reynoso de Guarlalajara, Jalisco. 
que en el siglo xvi hubo un plagio inescrupuloso, por parte de grabadores e impresores, sobre las obras originales de artistas tan reconocidos como Shöngahuer, Holbein y el propio Durero, de cuyas dos versiones sobre el Apocalipsis, se desprenden, como eco lejano, algunas de las pinturas de Gerson. La ciudad de Lyon alcanzó enorme prestigio en el siglo xvi, por las múltiples casas de impresores que habia en ella; los libros lyoneses circulaban por toda Europa y pronto llegaron a América al través del amparo español, hasta el día en que Felipe II creó el monopolio de libros litúrgicos al nombrar Impresor Real a Cristóbal Plantin, establecido en Amberes. 20

Al trabajar Juan Gerson en sus pinturas para la bóveda del sotocoro de la iglesia de los franciscanos de Tecamachalco, lo hizo con una notable libertad respecto a la composición y las figuras mismas que aparecen en los grabados. Las composiciones las modificó obligado, sin duda alguna, por la forma ovoide que se dio a los lienzos; asf, por ejemplo, algunos pasajes que en las láminas aparecen apaisados, como en el caso de La torre de Babel, figs. 10, 11, Gerson en su pintura rompió con el modelo para adaptar en un sentido vertical su composición. Otro de los casos frecuentes en que alteró los modelos, es aquel en el que suprimió personajes, o bien les dio una colocación distinta a la que tenían en el grabado. Pero en algún caso, como veremos, invirtió por completo las figuras; es decir, las que aparecen en las láminas al lado izquierdo, en las pinturas están en el lado opuesto. Y como no podía ser menos, en ciertas interpretaciones de los pasajes de las Sagradas Escrituras, así como los personajes que en ellos intervienen, todo fue modificado en un buen número de casos; esos pasajes el artista los trató de la mejor manera que pudo entenderlos, a pesar del fraile que debió estar a su lado, cuidando que no cayera, precisamente, en confusiones peligrosas, pues es necesario no olvidar la condición espiritual en que estaba colocado este tlacuilo, el cual distaba mucho, con toda seguridad, de haber asimilado bien la nueva religión para la que trabajaba. Entre las modificaciones que introdujo, acaso las más valiosas, están esos elementos formales derivados de la vieja cultura indígena, mismos que hemos señalado atrás. Si todos los copistas se permiten pequeñas libertades con las que alteran aquello que copian, Juan Gerson no tenía por qué

20 Mayores noticias sobre los impresores y la influencia de los grabados europeos en el arte colonial americano, los encontrará el lector en las siguientes obras: Pál Kelemen, Baroque and Rococo in Latin America. The Macmillan. New York, 1951, pp. 200-203. Martin S. Soria, La Pintura del Siglo XVI en Sud América. Instituto de Arte Americano e Investigaciones Estéticas. Buenos Aires, 1956, pp. 86-88. 
ser una excepción, máxime cuando él estaba adentrándose, apenas, en un mundo de formas e ideas que no eran ciertamente las del pueblo al que él pertenecía.

Una rebosante y alegre ingenuidad es la que se desprende del Arca de Noé, que Gerson pintó con vivos colores; sin embargo, la pintura es muy semejante al grabado de donde salió, a pesar de un problema con el cual el artista batalló sin llegar a resolver: el de la escala de las figuras. Por otra parte, exageró sobremanera la clavazón de los maderos del arca. La composición que en el grabado es apaisada, en la pintura resultó de tipo circular, figs. 8 y 9 .

Más que el constructor de la legendaria Torre de Babel, el personaje pintado por Juan Gerson tiene un franco carácter de predicador luterano; en cuanto a los peones y canteros que le acompañan, éstos fueron tratados con una gran libertad por el pintor, hizo de ellos unos artesanos casi adolescentes, los cuales trabajan en un mundo que más tiene de fantástico que de real, con lo que se contribuyó para hacer de este cuadro una de las obras más curiosas y sobresalientes de cuantas se encuentran allí, figs. 10 y 11 .

La pintura sobre El Sacrificio de Isaac, a semejanza de la estampa de donde ha salido, nos muestra una superposición de escenas: el camino de Isaac hacia su holocausto y el momento en que va a ser sacrificado por Abraham. La diferencia que existe entre la pintura y su modelo, radica en que en la primera, la composición resultó más apretada; además, en ella no existe una profundidad de planos, mediante la cual adquieran escala propia las dos escenas, fig. 12. Idéntica superposición de temas encontramos respecto a Cain y $\mathrm{Abel}$, si bien aquí sí se dio profundidad al utilizar dos escalas, fig. 7. Nada tan difícil para la mentalidad de Juan Gerson, que varios de estos pasajes bíblicos; es por ello que hasta cómica puede resultarnos alguna de sus interpretaciones, como acontece con La escala de Jacob; con enorme azoro éste contempla -y no sueña conforme al Génesis-como ascienden por la escalera esos tres ángeles que surgen, nada menos que de sus entrañas, fig. 13.

El burdo cancel de madera que está colocado frente a la puerta de la iglesia, oculta tres de las pinturas: el medallón circular con el símbolo del evangelista San Mateo y dos pinturas referentes a los primeros pasajes del Apocalipsis de San Juan. Por fortuna me ha sido posible verlas; las dos pinturas son casi idénticas a los grabados que reproducen las figuras 16 y 17 . Su color es más limpio, se ha conservado mejor 
bajo los maderos que las cubren y, sobre todo, no se les ha retocado como ocurrió con los otros óvalos, 21

Es indudable que el grabado que representa a Los cuatro jinetes del A pocalipsis, está inspirado en la célebre estampa que Alberto Durero grabó en 1498 con el mismo tema; de allí han salido casi todas las versiones que se han grabado después del gran maestro de Nuremberg. Es muy probable que Durero no habría hecho otra cosa que sonreír, ante la deliciosa e ingenua interpretación que en la lejana y desconocida América, un pintor indígena hiciera de su lámina con tal desenfado. Esta es una de las pinturas más atractivas de Tecamachalco; lo es tanto por su colorido como por la espontaneidad, casi infantil, con que está abordaclo el tema. Gracia y soltura de imaginación hay en Ios cuatro caballos y lo mismo acontece con el jinete de la muerte, puesto que cabalga y arremete en una postura imposible. En cuanto al jinete que porta la balanza, Gerson se permitió cubrirlo con una lujosa armadura, figs. 20 y 21 . La cabeza del monstruo que simboliza el infierno se exageró notablemente. 22

Respecto a la pintura La apertura del Quinto Sello, deseo llamar la atención sobre la hermosa figura que de pie, está colocada casi al centro; si se compara con el grabado de la Biblia de 1558, es bien distinta en más de un detalle, lo es en sus rasgos físicos y en la singular manera en que se le ciñe al cuerpo la túnica que viste. Todo nos induce a pensar en alguna lámina de origen italiano, por el plegado de la túnica que es característico en las vestiduras de las pinturas florentinas de principios del siglo xvi, figs. 22 y 23. Pero el cuadro de Gerson tiene otro detalle que bien merece nuestra consideración. Surgiendo de la tierra aparece recostada una pareja formada por un hombre $y$ una mujer, ambos están desnudos como convenía a tal situación, más obsérvese cómo ocultan candorosamente con las manos, sus sexos; ahora bien, salvo estas figuras, casi desnudas por completo, Gerson no se ocupó de nueva cuenta, sobre la desnudez física del hombre y la mujer. Las pinturas del sotocoro de Tecamachalco, junto con los murales que tuvo el convento, desempeñaban una función pedagógica, de enseñanza religiosa; es por ello que no deja de ser curioso el hecho de que el artista

21 Ojalí algún día sea retirado el horrendo cancel que las cubre, sólo asl se podrá admirar completo este conjunto de interesantes pinturas.

22 El símbolo del infierno representado por una monstruosa cabeza de cuyas fauces salen llamas, tiene su origen en la Edad Media. En la pintura colonial este símbolo aparece constantemente y llega, inclusive, hasta los grabados de José Guadalupe Posada. Un estudio iconográfico del mismo, sería interesante. 
no haya ilustrado uno de los principales temas bíblicos del Génesis: el de Adán y Eva. El tema se prestaba muy bien para indicar a los nuevos fieles, cuál era el origen del hombre desde el punto de vista de la nueva religión. Sin embargo, existía un problema ecómo presentarles desnudos ante los ojos de los indios? Por lo tanto, el pasaje se suprimió. El desnudo en la pintura colonial se convierte desde el siglo Xvi, en un tabú para artistas y creyentes; no existía razón alguna para que aqui fuera una excepción con respecto a la pintura española peninsular, en la cual, comq se sabe, no se permitió.

Para pintar Juan Gerson el capítulo vil del Apocalipsis, versículos 1 a 4, o tuvo por modelo una lámina distinta a la que aquí se reproduce, o le hizo tales modificaciones que su pintura resultó enteramente distinta; me inclino hacia lo segundo. Gerson modificó en tal forma la composición del pasaje sobre Los elegidos de la tribu de Israel, que inclusive invirtió hasta las figuras mismas, como podrá constatarse en las ilustraciones 26 y 27. Por más que pintura y grabado parezcan distintos, no puede negarse que el orden de la composición fundamental, está allí.

Si no es con algo de buen humor no se podrá entender la ingenuidad, casi infantil, con la que se pintó $E l$ castigo de las langostas, figs. 30 y 31. A decir verdad las langostas de Gerson no andan muy lejos de la estampa de donde salieron; pero en la pintura más que langostas, éstas parecen unos pequeños y asquerosos monstruos que llevan grandes bigotes blancos, en lugar de agudos colmillos; mucho de caricaturesco hay aquí. En cuanto a las sierpes que llevan por cola, ya se ha indicado el realismo que se puso en ellas.

Sobre la pintura de Los cuatro ángeles del abismo, mucho de lo ya anotado se puede repetir. En primer lugar creo que Juan Gerson procedió en este caso con una gran libertad, misma que le permitió invertir el orden de las figuras; es decir, si en el grabado los cuatro jinetes marchan hacia la derecha, en la pintura van en sentido opuesto. Las colas de los monstruos en que cabalgan estos jinetes "vestidos con corazas como de fuego...", son unas serpientes muy semejantes a las que aparecen en la pintura anterior. $Y$ en cuanto a la lucha que sostienen los jóvenes ángeles, no se puede menos que sonreír por la ingenuidad puesta en ella.

Franca imitación de un conocidísimo grabado de Alberto Durero, es la xilografía que se reproduce en la figura 34 . La copia que nuestro artista ha hecho en su pintura, no puede ser más semejante, pese a algún detalle de más o de menos que aparece en el paisaje, fig. $y_{5}$. 
El desconocido grabador que trabajó las láminas que ilustran esta edición de la Biblia de 1558, dependió en mucho de cualquiera de las versiones del Apocalipsis, creadas por Alberto Durero, o de alguno de los imitadores de éste. La huella de Durero aparece también en la estampa de La mujer y el dragón, misma que Juan Gerson llevó a su lienzo, figs. 36 y 37 . Como en casos anteriores esta pintura nos muestra hasta dónde su propia iniciativa le permitió modificar el modelo que tenía ante los ojos. La innovación principal está concentrada en la ima. gen de la mujer apocalíptica. Por lo pronto, la túnica que ésta viste le cae lisa y llanamente hasta los pies; los pliegues que aparecen en el grabado, Gerson los evitó. Pero, de nueva cuenta, es en esta pintura donde queda delatada la presencia atávica de la vieja estética prehis. pánica: en las alas que ha puesto a la mujer. En efecto, en esas alas hay mucho de las pinturas y esculturas del mundo aborigen; esas puntas de plumas que salen hacia las orillas, no pueden menos que recordarnos los antecedentes que tienen en las águilas de los códices; en todo caso, su diseño es semejante al águila que encontramos esculpida en la lápida puesta al pie de la torre, y lo mismo acontece con las que aparecen en la puerta de la Porciúncula.

Las pinturas restantes, comparadas con los grabados de donde salieron, sólo nos permiten ver hasta dónde el artista se concedió ciertas libertades sobre aquello que copiaba. Muchas de estas modificaciones debieron obedecer a lo oscuro e incomprensible que para Gerson, eran la mayor parte de los temas b́fblicos. Algún grabado, como el del Cortejo del Cordero, pasó íntegro a la tela como podrá verse en las ilustraciones 40 y 41 . Salvo algunas variantes, otro tanto puede decirse respecto al pasaje que aparece en la figura 43. En lo que sí varían fundamentalmente las pinturas, respecto a los grabados, es en la nota constante de sencilla ingenuidad que Juan Gerson puso en cada obra; el ángel que encadena al demonio...., es una prueba elocuente de ello, fig. 42.

Es probable que las pinturas de Tecamachalco sean las únicas que subsistan de todas cuantas pintó el tlacuilo Juan Gerson. Sin embargo, no hay que descartar la posibilidad de que algún día aparezcan otras, bien en las iglesucas de los barrios de Tecamachalco, o en el pueblo vecino de Quecholac que tantas relaciones sostuvo con aquél; además hay que tener presente a Tepeji de la Seda, pueblo del que fue gobernador don Tomás Gerson, posible hermano o en todo caso, pariente muy allegado a nuestro artista. Futuras investigaciones habrán de ampliar las noticias que por hoy poseemos. 
Dentro del proceso de transculturación operado en México, una vez calmada la violencia de la conquista, la obra de Juan Gerson se nos presenta como un valioso ejemplo, mediante el cual se puede constatar dicho proceso, en el terreno particular de las artes plásticas. Juan Gerson no es el único artista indígena que haya asimilado amplia y prontamente la cultura occidental; se tienen noticias de otros artistas cuyo número es considerable hacia la cuarta y quinta década del siglo xvı; por desgracia las obras que hicieron hoy sólo las conocemos merced a los documentos que guardan su memoria. Es por ello que el caso de Gerson es el más notable, de cuantos tenemos conocimiento, respecto a la transculturación en la pintura. ${ }^{23}$

23 Para realizar esta investigación el autor conto con la inestimable ayuda de las siguientes personas: profesor René Solís, doctor David Erlij y profesor Enrique Berlin. Al señor don Jesús Espinosa $H$., se deben las magnificas fotografías de la obra de Juan Gerson, gracias a él por primera vez se publica completa. Las fotografias de los grabados fueron tomadas por Elisa Vargas Lugo y el dibujo de la bóveda fue hecho por el arquitecto Carlos Blackaller C. Para todos soy deudor agradecidísimo. 